\title{
PestLCl 2.0 sensitivity to soil variations for the evaluation of pesticide distribution in Life Cycle Assessment studies
}

Fantin, Valentina; Buscaroli, Alessandro; Dijkman, Teunis ; Zamagni, Alessandra; Garavini, Gioia; Bonoli, Alessandra; Righi, Serena

Published in:

Science of the Total Environment

Link to article, DOI:

10.1016/j.scitotenv.2018.11.204

Publication date:

2019

Document Version

Peer reviewed version

Link back to DTU Orbit

Citation (APA):

Fantin, V., Buscaroli, A., Dijkman, T., Zamagni, A., Garavini, G., Bonoli, A., \& Righi, S. (2019). PestLCl 2.0 sensitivity to soil variations for the evaluation of pesticide distribution in Life Cycle Assessment studies. Science of the Total Environment, 656, 1021-1031. https://doi.org/10.1016/j.scitotenv.2018.11.204

\section{General rights}

Copyright and moral rights for the publications made accessible in the public portal are retained by the authors and/or other copyright owners and it is a condition of accessing publications that users recognise and abide by the legal requirements associated with these rights.

- Users may download and print one copy of any publication from the public portal for the purpose of private study or research.

- You may not further distribute the material or use it for any profit-making activity or commercial gain

- You may freely distribute the URL identifying the publication in the public portal 
See discussions, stats, and author profiles for this publication at: https://www.researchgate.net/publication/329014637

\section{PestLCI 2.0 sensitivity to soil variations for the evaluation of pesticide distribution in Life Cycle Assessment studies}

Article in Science of The Total Environment · November 2018

Dol: 10.1016/.jscitotenv.2018.11.204

\section{CITATIONS}

7 authors, including:

Valentina Fantin

ENEA

39 PUBLICATIONS 264 CITATIONS

SEE PROFILE

D) Alessandra Zamagni

Ecoinnovazione spin-off ENEA

101 PUBLICATIONS 2,469 CITATIONS

SEE PROFILE

Some of the authors of this publication are also working on these related projects:

Industrial Symbiosis View project

Project International Social LCA Forum View project
106

Alessandro Buscaroli

University of Bologna

28 PUBLICATIONS 340 CITATIONS

SEE PROFILE

(2) Gioia Garavini

12 PUBLICATIONS 8 CITATIONS

SEE PROFILE 


\section{PestLCI 2.0 sensitivity to soil variations for the evaluation of pesticide}

\section{distribution in Life Cycle Assessment studies}

Valentina Fantin ${ }^{1,5^{*}}$, Alessandro Buscaroli ${ }^{2}$, Teunis Djikman ${ }^{3}$, Alessandra Zamagni ${ }^{4}$, Gioia Garavini $^{4}$, Alessandra Bonoli ${ }^{5}$, Serena Righi $^{2}$

${ }^{1}$ ENEA - Italian National Agency for New Technologies, Energy and Sustainable Economic Development, Via Martiri di Monte Sole 4, 40129 Bologna, Italy

${ }^{2}$ Interdepartmental Research Centre for Environmental Science - CIRSA, Alma Mater Studiorum University of Bologna, Via S. Alberto 163, 48123 Ravenna, Italy

${ }^{3}$ Division for Quantitative Sustainability Assessment. DTU Management Engineering. Produktionstorvet, building 424 DK-2800 Kgs. Lyngby, Denmark.

${ }^{4}$ Ecoinnovazione SRL, Via D’Azeglio, 51, 40123 Bologna (BO), Italy

${ }^{5}$ Department for Civil, Chemical, Environmental and Materials Engineering, Alma Mater Studiorum University of Bologna, Via Terracini 28, 40131, Bologna, Italy.

*Corresponding Author:

Valentina Fantin

E-mail address: valentina.fantin@enea.it

Tel.: + 390516098532

fax: +390516098280

Keywords: Life Cycle Inventory, Pesticide emissions, Tillage, Pedology, Groundwater 


\section{ABSTRACT}

Pesticides are commonly applied in conventional agricultural systems, but they can lead to serious environmental contamination.. The calculation of on-field pesticide emissions in Life Cycle Assessment (LCA) studies is challenging, because of the difficulty in the calculation of the fate of pesticides and, therefore, several literature approaches based on different dispersion models have been developed. PestLCI 2.0 model can provide simultaneous assessment of the emission fractions of a pesticide to air, surface water and groundwater based on many parameters. The goal of this study is to exploit the extent of PestLCI 2.0 sensitivity to soil variations, with the ultimate goal of increasing the robustness of the modelling of pesticide emissions in LCA studies. The model was applied to maize cultivation in an experimental farm in Northern Italy, considering three tests, which evaluated the distribution of pesticides among environmental compartments obtained considering different soil types.

Results show that small variations in soil characteristics lead to great variation of PestLCI 2.0, with a significance that depends on the type of environmental compartment. The compartment most affected by soil variations was groundwater, whereas surface waters were dominated by meteorological conditions, pesticides' physical and chemical properties and wind drift, which are independent from soil characteristics.

Therefore, the use of specific soil data in PestLCI 2.0 results in the availability of a comprehensive set of emission data in the different compartments, which represents a relevant input for the inventory phase of LCA studies and can increase their robustness. Nevertheless, PestLCI 2.0 requires a great effort for the data collection and a specific expertise in soil science for interpreting the results. Moreover, characterization factors for pesticide groundwater emissions should be developed, in order to exploit these detailed results in the impact assessment phase, Finally, the study provides further insights into future improvement of PestLCI 2.0. 


\section{Introduction}

Pesticides have been used intensively in agriculture to boost food production, but they can result in severe environmental contaminations (Damalas and Eleftherohorinos, 2011; Verna et al., 2014). It has been reported that pesticides applied to crops cultivation are degraded in several ways described as biotransformation, biomineralization, bioaccumulation, biodegradation, and cometabolism (Finley et al., 2010; Park et al., 2003; Shakoori et al., 2000 ).

Pesticide biodegradation is a soil microbial function of critical importance for modern agriculture and its environmental impact (Dechesne et al., 2014). A few biodegradation controlling factors have tentatively been identified across pesticide classes. They include some soil characteristics as $\mathrm{pH}$ (Lauber et al., 2009; Rasmussen et al., 2005; ;), soil moisture (Hussain et al., 2013), Carbon/Nitrogen ratio and Potassium (Rasmussen et al., 2005), organic matter and clay Vinther et al., 2008). Other soil properties and characteristics partially related to tillage practice such as macropores (Nielsen et al., 2010), structure and cracks (Alletto et al., 2008) and soil horizons also have impact on pesticide degradation.

Life cycle assessment (LCA) methodology has been widely applied to agricultural production chain (Notarnicola et al., 2017). Nevertheless, LCA studies of agri-food systems have to face several challenges, among others the modelling of emissions from pesticides at the inventory analysis level (Goglio et al., 2014; Schmidt Rivera et al., 2017;), which can lead to important environmental impacts due to their chemical, toxicological and eco-toxicological properties (Notarnicola et al., 2017). The criticalities in modelling are due to several factors. Firstly, since data about pesticide production are frequently not available, the practitioner often uses estimates for the assessment, or excludes them from the study (Fantin et al., 2017; Notarnicola et al., 2015; Schmidt Rivera et al., 2017). Moreover, even when the active ingredients are considered, the pesticide formulation by- 
products (adjuvant, solvents, etc.) are omitted from the analysis (Rosenbaum et al., 2015). Secondly, on-field emissions due to the use of pesticides are extremely difficult to measure and therefore they must be estimated by dispersion models.

As regards the estimation of on-field emissions from pesticides application, the main difficulty in LCA studies is the quantification of the mass emitted to the different environmental compartments (i.e. air, soil, water), because only the amount applied to the agricultural field is known (Rosenbaum et al., 2015). Furthermore, other problems can affect the inclusion of pesticide field emissions, such as the lack of knowledge about toxicological properties of chemicals (European Commission, 2001) and the complexities in toxicity effect modelling (IEA Bioenergy, 2015). Moreover, the fate of pesticides' active ingredients depends on site-specific soil and climate conditions, the location of the water table and farming practices (Notarnicola et al., 2015).

Until the 1990s, Life Cycle Impact Assessment (LCIA) methodsdid not consider pesticides' fate in the environment for their impact assessment but only their toxicity and ecotoxicity (Margni et al., 2002; Kramer, 2003). During the 1990s, the LCA scientific community started to propose methods, such as Eco-Indicator 98 or USES-LCA (Huijbregts et al., 2000) for predicting the fate of pollutants, pesticides included, in the different environmental compartments. In the early 2000s, Margni et al. (2002) presented a model which assumes that $10 \%$ of the applied active ingredient remains in the air, $85 \%$ enters the soil and 5\% remains on the leaves .. Moreover, the Ecoinvent Database proposed the accounting of pesticides application as full emissions into agriculture soil (Nemecek and Erzinger, 2005; Nemecek and Kägi, 2007). In 2006, a more sophisticated model called PestLCI 1.0 was developed (Birkved and Hauschild, 2006), which provides simultaneous assessment of the emission fractions of a pesticide to air, surface water and groundwater based on the application method, local climate conditions, crop type and soil data. In 2012, Dijkman et al. presented PestLCI 2.0, an updated and expanded version of PestLCI 1.0 (Dijkman et al., 2012). 
Currently, several methodological approaches are available for the estimation of fate and transport processes of pesticides after the application to agricultural fields. Therefore, the quantification of life cycle emission inventories of pesticides in LCA studies is not harmonised, and the diversity of these approaches lead to different results, thus compromising the reliability of LCA outcomes for agricultural products especially in case of comparative studies (Notarnicola et al., 2015; Rosenbaum et al., 2015). For this reason, a consensus on the delineation between pesticide emission inventory and impact assessment for LCA is necessary (Rosenbaum et al., 2015). This opinion is reiterated in the Product Environmental Footprint Category Rules (PEFCR) Guidance (European Commission, 2017) where, as a temporary approach, the following pesticide distributions are suggested: $90 \%$ emitted to the agricultural soil compartment, $9 \%$ emitted to air and $1 \%$ emitted to water. The PEFCR Guidance asserts that the PestLCI 2.0 model might fill in the gap between the amount of pesticides applied on the field and the amount ending up in the emission compartment in the future, but is currently still under testing (European Commission, 2017).

In accordance with these statements, the use of PestLCI 2.0 has recently increased in LCAs of food products, and it has been applied to maize and wheat (Bacenetti et al., 2014; Bacenetti et al., 2015) and barley (Niero et al., 2015a; Dijkman et al., 2017; Schmidt Rivera et al., 2017) cultivation assessment. Nevertheless, while the simplified approaches defined by Margni et al. (2002) or Nemecek and Kagi (2007) do not require detailed information in terms of on-site data, the use of more sophisticated models such as PestLCI 2.0 requires specific data about the application method as well as soil and climate data of the studied region, which can be difficult to obtain for the LCA practitioner. Some studies have adapted PestLCI to other climate, soil-specific and crop-specific conditions (Niero et al., 2015b; Renaud-Gentié et al., 2015; Schmidt Rivera et al., 2017), but, to the best of our knowledge, no study has assessed the variations in active ingredients emissions to the different environmental compartments according to soil variations. Therefore, the aim of this study is both to evaluate PestLCI 2.0 sensitivity to soil variations and the extent to which the modelling of 
pesticide emissions in LCA studies can be increased in accuracy, while preserving the applicability. The ultimate goal is threefold: i) i) to provide indications to LCA practitioners on PestLCI benefits and difficulties; and ii) to provide information to LCIA model developers on pesticide emissions into the environmental compartments; iii) to provide feedback to PestLCI developers on its responses to the variations of soil features. To this purpose, PestLCI 2.0 was applied to a maize production case-study in the experimental farm of Vallevecchia, located in the province of Venice (Northern Italy) using site-specific data versus different soil data.

\section{Materials and Methods}

\subsection{PestLCI 2.0 model description}

The model PestLCI 2.0 (Dijkman et al., 2012) is intended for use in the Life Cycle Inventory analysis (LCI) phase of LCA, to quantify pesticide emissions from an agricultural field to surrounding environmental compartments. PestLCI 2.0 is an improved version of PestLCI 1.0 (Birkved and Hauschild, 2006), in terms of inclusion of new processes to model pesticide fate; modelling update of already included processes; broadening of the geographical scope of the model, so to include the whole Europe. The model is described briefly here, while a more detailed description is found in Dijkman et al. (2012). PestLCI 2.0 calculates pesticide emissions by modelling primary and secondary pesticide distribution in the 'field box', which describes the model boundaries. The 'field box' contains the field where the pesticide is applied, the soil up to 1 $\mathrm{m}$ depth and the air above the field up to $100 \mathrm{~m}$. The soil, water, air and crop within the field box is considered as part of the technosphere. A pesticide becomes an emission to the ecosphere when it crosses the 'field box' borders.

Primary pesticide distribution includes deposition on leaves and on field soil, as well as wind drift, which is the transport, due to wind, of pesticide droplets leaving the sprayer across the field border. 
After the primary distribution has been calculated, the secondary distribution describes the fate of the pesticide that is deposited on the plants in the field and on the field soil.

The secondary processes considered in PestLCI 2.0 are pesticide degradation, uptake into the leaves, and volatilization, which leads to an emission to air. The processes on leaves are modelled until the first rainfall event occurs after pesticide application. At that point, all remaining pesticide is assumed to wash off into the top soil.

The secondary processes considered on top soil (defined as the uppermost $1 \mathrm{~cm}$ of soil) are pesticide degradation and volatilization, which, like the secondary processes on leaves, are modelled until the first rainfall event after application. Once this has happened, the emission to offfield surfaces due to runoff is calculated. In PestLCI 2.0, only emissions of pesticide dissolved in runoff water are calculated. Moreover, the amount of dissolved pesticide entering macropores is calculated.

After the first rainfall event, all pesticide left in the soil is assumed to remain at the bottom of the topsoil. From here, the pesticide starts leaching through the soil until it reaches $1 \mathrm{~m}$ of depth. At this depth, it is considered an emission to groundwater. For leaching modelling, the soil is considered a column through which water moves downwards at a constant rate. In contrast with the terminology used in Dijkman et al (2012), pesticide emissions to off-field surfaces rather than to surface water are reported, because the border of a field is not necessarily made up of water bodies. Off-field surfaces can be surface water, agricultural soil or natural soil. In addition, emissions due to wind drift are characterized as emissions to off-field surfaces, instead of emissions to air. This is not consistent with the field borders, because airborne droplets leave the 'field box' via air. However, these droplets are typically deposited near the field, and the available data to calculate wind drift is based on deposition measurements (Holterman \& Van de Zande, 2003). As current characterization models used in LCA do not account for the deposition of airborne droplets, it was decided to report wind drift as an emission to off-field surfaces. 
It is noteworthy that PestLCI 2.0 was developed for modelling European conditions, and specific local circumstances may not be reflected in the modelling. This might prevent the applicability of the model to different geographical areas, characterized by other soil and climate conditions, thus preventing from obtaining realistic results.

\subsection{Soil sensitivity evaluation method}

The sensitivity of PestLCI 2.0 to soil variations was evaluated by means of three comparative tests:

- $\quad \therefore$ test 1: comparison between the distribution of pesticide obtained considering several types of soils with similar characteristics (i.e. organic carbon content, $\mathrm{pH}$, clay, silt and sand content) to the Vallevecchia soil and the site-specific one (i.e. the Vallevecchia soil);

- test 2: comparison between the distribution of pesticide obtained using types of soils different in their characteristics to the Vallevecchia soil and the site-specific one.

- test 3: comparison between the distribution of pesticide obtained applying the soil data of Vallevecchia site and the distribution obtained using the PestLCI 2.0 default soil (i.e. contained in the model's database), which was considered more similar to the site-specific one.

\subsection{Experimental farm description}

The experimental farm of Vallevecchia extends for 900 hectares in a reclaimed territory bounded by sea, lagoons and fluvial waters (ARPAV, 2018a). Since Vallevecchia is an experimental farm, its field area is small (0.35 ha).and the following four crops are cultivated: maize, soybean, wheat and rapeseed. For this case study, maize was chosen for the application of PestLCI 2.0 model. y Sitespecific soil and climate parameters, described in the following paragraphs, were added in PestLCI 2.0 database for this purpose.

\subsubsection{Climatological data}


Climatological data have been obtained from the monitoring network of Veneto Regional Agency for Environmental Prevention and Protection (ARPAV), Meteorological Centre of Teolo (CMT) (ARPAV, 2018b). The data acquired at the station n. 166 of Lugugnana (Portogruaro), $0 \mathrm{~m}$ above sea level, coordinates 1807248 m E, 5068864 m N, Gauss-Boaga datum (Italian Fuse Ovest) refer to the period 1994-2014. Unfortunately, a longer climatological series could not be considered because Lugugnana station was activated only in 1992.,

\subsubsection{Soil data}

Soil data were collected from the soil map of Veneto Region (ARPAV, 2016a). Every cartographic unit in the soil map is provided with a link to the list of the included Soil Typological Units (STU). Each STU is identified both by a name and by an acronym and is described in detail with the most relevant physical and chemical soil characteristics, the landscape unit and both the Soil Taxonomy (Soil Survey Staff, 1998) and the World Reference Base (FAO/ISRIC/ISSS, 1998) soils classifications. The studied site insists on reclaimed lagoon areas derived from the deposits of the Piave, the Livenza and the Tagliamento rivers. Soils described in this area and accounted for in the study (BIB1, CAB1, CAP1, CFO1, CON1, CRL1, CTU1, MEL1, QUA1, SAB1, SCO1, TDF1, VAD1, VAN1 and VED1) are generally deep (>1 m), with a typical A/B/C or A/C horizons sequence (see explanation notes in Table 1 and Table 2), organic matter content ranging between $0.2 \%$ and $3.9 \%$ in surface horizons and $\mathrm{pH}$ values ranging between 6.6 and 8.7 (Table 1 and Table 2). These soils differ mainly in texture, which is silty clay loam (CAB1, CFO1, CTU1, SCO1, TDF1) or silty loam (BIB1, CON1, CRL1, QUA1) or loam (MEL1, VAN1, VED1), or sandy loam (CAP1), or sandy (SAB1, VAD1). All soils are cultivated (suffix p in horizon designation). Some soils display the presence of water in some horizons (suffix g) and also the accumulation of secondary carbonates (suffix k). Some soils (CAB1 and CTU1) display the presence of organic horizons $(\mathrm{H})$ which lie, anyway, at a depth greater than $1 \mathrm{~m}$, and were therefore not considered in 
the computation (since they are out of the field border defined by PestLCI 2.0). These STU are all suitable for maize cultivation but they have different characteristics and limitations which provide different attitudes to crop production.

The studied Vallevecchia farm is located on the Torre Di Fine (TDF1) soil, whose characteristics are summarized in Table 1.

In order to perform the case study, as explained in section 2.2, the above-mentioned soils were divided in two groups: 1) similar soils, which have similar characteristics to TDF1 (test 1); 2) different soils, which have different characteristics from TDF1 (test 2). More in detail, the similar soils are the following (Table 1): CTU1; SCO1; CAB1; CFO1; CON1; BIB1; QUA1; CRL1. On the contrary, the following soils have different characteristics with regard to TDF1 (Table 2): VAN1; VED1; MEL1; CAP1; SAD1; VAD1.

As mentioned above, a further comparison was performed between the results of PestLCI 2.0 with TDF1 soil and those obtained with a comparable soil (Soil6) already contained in the model's database (test 3), which been selected on the basis of chemical and physical characteristics (Table 2). In fact, this soil has the same textural class as TDF1 and also a similar organic carbon content and $\mathrm{pH}$ value. The other soils in the database could not be considered since they have completely different properties.

\subsubsection{Crop and pesticide data}

In the studied area, maize is cultivated for silage production with conventional tillage technique, which consists of ploughing the soil and applying pesticides with the spray boom technique .

In the farm of Vallevecchia, three main phases for the use of pesticides can be identified: i) the preemergence phase, in which the pesticides are spread before seeding or before plants emerge from the soil; ii) post-emergence, which corresponds to the leaf development of the crop; iii) treatment with insecticides which corresponds to the inflorescence development. In the case-study, three 
active ingredients were applied: terbuthylazine, metolachlor and cypermethrin. Terbuthylazine and metolachlor were used in both pre- and post-emergence phases, whereas cypermethrin was used only for the treatment of insects (see Table 3). Data in Table 3 refer to the maize productive cycle of one year.

\section{Results and Discussion}

In this chapter the results of the three tests (explained in the section 2.2) are reported and discussed, namely:

1. TDF1 (site-specific soil) versus similar soils (test 1);

2. TDF1 versus different soils (test 2);

3. TDF1 versus Soil6 (reference default soil) (test 3);

Results consist of the percentage distribution of the pesticides among four fractions: emissions to air, surface water (or off-field soils) and groundwater, degraded fraction and fraction uptaken by plant or soils. Surface water and off-field soils (i.e. natural or agricultural soils located next to the field where the pesticide is applied) are considered equivalent from the fate point of view, since the actual final destination depends on the presence of water or soils near the analyzed field; they include emissions to surface water and wind drift. Airborne emissions are the sum of pesticide volatilization from leaves and top soil. Groundwater emissions are the sum of emissions through macropores and leaching through soil matrix.

\subsection{Results of Test 1: comparison among TDF1 and similar soils}

Table 4 shows the results of PestLCI for the comparison among TDF1 (site-specific soil) and similar soils. PestLCI results are expressed in fraction, i.e. they can vary from 0 to 1.

Firstly, it is noteworthy that the fraction degraded or uptaken by plants or soils varies greatly on the basis of the pesticide. As regards terbuthylazine in TDF1, this fraction is $0.6-0.7$, so a significant fraction is emitted to environmental compartments. It can be observed that emissions to air increase 
slightly from pre-emergence to post-emergence application (0.093-0.12 respectively), while the emissions to groundwater decrease slightly from pre-emergence to post-emergence $(0.25-0.17)$. On the contrary, the fraction of metolachlor and cypermethrin degraded or uptaken in TDF1 is always higher than 0.9 and often reaches 0.99 . Therefore, the fraction emitted to air and water for TDF1 is small or negligible. Moreover, the period of pesticide application appears not to affect the fraction degraded or emitted. In fact, the fraction of terbuthylazine degraded or uptaken for TDF1 during the pre-emergence is very similar to the one degraded or uptaken in post-emergence. The same occurs for metolachlor in TDF1. Similar trends of pesticides distributions are observed also in the other soils.

As far as the comparison among the site-specific soil (TDF1) and the soils with similar features is concerned, results highlight that both the emissions to air and surface water (or off-field soils) are scarcely affected or completely not affected by soil variation, with the exception of metolachlor in pre-emergence.

As regards emissions to air, it is noteworthy that pesticide volatilization from leaves and top soil depends mainly on meteorological conditions, on pesticide chemical properties and on both $\mathrm{pH}$ and organic carbon content of soil. Despite some differences in organic carbon content in considered soils (from $0.2 \%$ to $2.3 \%$, see Table 1 and Table 2 ) the role of soil seems negligible in these cases. Terbuthylazine and cypermethrin show virtually identical values of airborne emissions for all soils. The volatilization of terbuthylazine comes mainly from top soil (order of magnitude $10^{-1}$ ) and in a minor amount from leaves (order of magnitude $10^{-3}$ ). In spite of this, the soil properties have little influence on the emissions to air, since terbuthylazine has a very low organic carbon partitioning coefficient $\left(\mathrm{K}_{\mathrm{oc}}\right)$ at the $\mathrm{pH}$ of the studied soils and therefore the pesticide volatilizes easily. In contrast, for cypermethrin, volatilization from soil occurs with at a very low rate (range from 4.0E10 to $9.0 \mathrm{E}-10$ ), meaning that emissions to air are dominated by volatilization from leaves (ranging from 4.0 E-04 to 5.0E-04) and the soil variations are irrelevant. Also metolachlor volatilizes mainly 
from leaves but its $\mathrm{K}_{\mathrm{oc}}$ permits a slight soil volatilization. A high differentiation among the soils is found in pre-emergence (c.v. $=59.5 \%)$, while the variation decreases in post-emergence (c.v.= 4.5\%). The decrease in differentiation after emergence is explained by the fact that in metolachlor emissions to air due to volatilization from leaves (about 2.0E-03) are typically 2 orders of magnitude higher than emissions due to volatilization from soil (range from 9.0E-05 to 1.5E-04). Before emergence there are no leaves, so that the variation in emissions resulting from differences in soil properties is visible.

Emissions to surface water (or to off-field soil) seem to be even less affected by soil characteristics if compared to emissions to air for all pesticides both in pre and post-emergence (the maximum c.v. is $6.2 \%$ observed in terbuthylazine in pre-emergence). More in detail, emissions to surface water (or to off-field soil) consist of two contributions: wind drift loss and runoff, where the former is always at least one order of magnitude higher than the latter. The value of wind drift loss is only correlated to the application technique and the field size, which is the same for all the soils. Therefore, the results of PestLCI 2.0 show that these values are completely independent from soil type. On the contrary, runoff fraction is strictly correlated to the characteristic of soil but it has a minor contribution on the total fraction emitted to surface water (or to off-field soils). The reason for wind drift dominating the off-field surface emissions is twofold: the modelled field size is small, resulting in more drift (the larger the field, the more drifting pesticide is deposited inside the field), and the slope of the field is 0 , so that water does not readily start running off.

In contrast, Table 4 shows that soil type remarkably affects the emissions to groundwater (c.v. is $15-40 \%$ ) although the characteristics of the nine soils analyzed are quite similar. Emissions to groundwater consist of emissions due to: i) leaching through the soil matrix and ii) emissions through macropores. As regards leaching, Pest LCI 2.0 models the soil as a column through which water moves downwards taking the pesticide with it. However, the pesticide moves slower than water, because it is absorbed by soil. The factor that determines how much slower the pesticide 
moves compared to water is calculated from the density of the soil and its organic carbon content, which differs per soil horizons.

Regarding macropores, it is important to notice that the total pore volume is the volume of water and air in the soil. PestLCI 2.0 splits pores into immobile and mobile ones on the basis of the fractions of sand, silt, and clay. Sand fractions give more mobile pores than clay fractions, reflecting the fact that water moves faster through sandy soils. Next, the mobile pores are split into slow and fast pores on a fixed 70/30 basis for all soil types. The fast ones are considered macropores (with a diameter $>8 \mathrm{~mm}$ ). When it rains, the pores are filled, starting with the immobile pores, then the slow mobile, and eventually the fast mobile. Sandy soils have more mobile pores and can therefore store more water (because water moves faster in mobile pores than in immobile), therefore the pesticide reaching groundwater through macropore flow is lower (Hall, 1993).

The weight of leaching contribution and the weight of macropores contribution depend on the type of pesticide. In this study, the relevance of transportation through macropores and that of leaching through the soil matrix are different for the three pesticides. The fraction of terbuthylazine which reaches groundwater through soil leaching (about from 1.5E-01 to 2.0E-01) is about one order of magnitude higher than that from macropores (about 2E-02). In the case of metolachlor, the two fractions are more or less of the same order of magnitude (about 1.5E-03-2.0E-03). Finally, the fraction of cypermethrin which reaches groundwater through macropores (from 1.0E-06 to 9.0E-07) is four-five orders of magnitude lower than that coming from soil matrix (about from 4.0E-02 to 7.0E-02). Correlation analysis among leaching through the soil matrix and soil characteristics (content of clay, silt and sand, $\mathrm{pH}$ and organic carbon percentage) do not highlight any particular trend. On the contrary, a strong inverse linear correlation between emissions through macropores and organic carbon percentage $(r>-0.9, p=0.001)$ is evident for metolachlor and cypermethrin. There is not such evidence for terbuthylazine and that could be due to its very low $\mathrm{K}_{\mathrm{oc}}$ at the $\mathrm{pH}$ of the studied soils. 
In conclusion, although the relationship between soil characteristics and the fractions of pesticide reaching groundwater is affected by many parameters, results show that soil characteristics are of primary importance.

\subsection{Results of Test 2: comparison among TDF1 and different soils}

Table 5 shows the results of PestLCI (expressed in fraction) for the comparison among TDF1 and the different soils. Table 5 shows that emissions to air of terbuthylazine are not affected by e soil characteristics (c.v. $=0.1 \%$ and $0 \%$ for pre-emergence and post-emergence, respectively) and also emissions to surface water are slightly affected by soil type $(2.7 \%$ and $1.8 \%$ for pre-emergence and post-emergence, respectively). On the contrary, soil typology remarkably affects the emissions to groundwater: in this case different soil characteristics lead to very different results (c.v. is over $90 \%$ in both pre and post-emergence). The comparison between Table 4 and Table 5 shows that the coefficient of variation in the emissions to groundwater of terbuthylazine increases significantly.

As regards metolachlor, a very high differentiation in emissions to air among the soils is found in pre-emergence $($ c.v. $=141 \%)$. As far as metolachlor in post-emergence is concerned, the results of the emissions to air regarding the different soils are slightly different (c.v. $=21.6 \%)$ from Table 4 . Analogously to the results of Table 4, the decrease in differentiation of metolachlor in postemergence is explained by the fact that emissions to air due to volatilization from leaves are much higher than emissions due to volatilization from soil. As regards emissions to surface water, metolachlor shows very similar results for all soils in pre-emergence, with the exception of VAD1. In fact, the runoff contribution in VAD1 is one order of magnitude higher than those of the other soils and this is probably due to the high sand content of this soil type (97\%). In post-emergence, wind drift contribution is about two orders of magnitude higher than runoff fraction, therefore the soil does not affect the results. As regards emissions to groundwater, the results are significantly affected by soil type. In fact, the coefficient of variation is about $55 \%$, with a slight increase with 
respect to Table 4. Finally, the difference in the degraded or uptaken fraction is not significantly affected by the soil type.

As far as cypermethrin is concerned, the results of Table 5 show that emissions to air and to surface water are not affected by the soil characteristics, because the contribution of volatilization from leaves and wind drift are about four/five orders of magnitude higher than the contribution of top soil volatilization and runoff respectively. As regards emissions to groundwater, the soil type significantly affects these values. In fact, the coefficient of variation is $133 \%$, with a great increase with respect to Table 4. Finally, degradation or uptake is not significantly affected by the soil type.

Contrary to data concerning the similar soils, data of leaching through the soil matrix concerning the different soils (Table 5) shows a good direct linear correlation with clay and silt content ( $\mathrm{r}=0.9$, $\mathrm{p}=0.01$ for terbuthylazine and cypermethrin $\mathrm{r}=0.7, \mathrm{p}=0.06$ for metolachlor) and a good inverse linear correlation with sand content $(\mathrm{r}=-0.8, \mathrm{p}=0.02$ for terbuthylazine and cypermethrin; $\mathrm{r}=-0.7$, $\mathrm{p}=0.06$ for metolachlor). In metolachlor and cypermethrin distribution, the strong inverse linear correlation between emissions through macropores and organic carbon percentage is confirmed also for the different soils group $(r>-0.85, p=0.009)$. On the contrary, there is no correlation between terbuthylazine reaching groundwater through macropores and organic carbon percentage

\subsection{Results of Test 3: comparison between TDF1 and Soil6}

Table 6 shows the results of the comparison between TDF1 and Soil6. Although similar trends in the emissions and degradation values for each pesticide and application period are observed in TDF1 and Soil6, the percentage differences between the two soils are, in some cases, significant or very high (Table 6). The maximum percentage difference can be observed for metolachlor in both pre and post-emergence, where these values can be about 500\%. The bigger differences concern the fraction emitted to groundwater, in particular the leaching fraction is one order of magnitude higher in Soil6 than in TDF1, while the fraction emitted to groundwater through macropores has the same 
order of magnitude in the two soils. Considering the discussion of Table 4 and Table 5, this large difference between the two soils in the fraction emitted to groundwater through the soil matrix could be due to the different content in sand. Indeed this characteristic is the one that differs the most from all the values observed in the other similar (Table 1) and different (Table 2) soils.

\subsection{Discussion and conclusions}

This study shows that variations in soil characteristics lead to variation of PestLCI 2.0 results concerning the distribution of the pesticides, with a significance that depends on the type of environmental compartment and the type of active ingredient. The compartment most affected by soil variations is groundwater, where both leaching through the soil matrix and emissions through

macropores are strictly related to soil features. On the contrary, emissions to air are dominated by meteorological conditions and pesticide physical and chemical properties, and emissions to surface water (or off-field soil) are dominated by wind drift, completely independent from soil characteristics.

Percentage distributions among soils located in nearby areas can have a coefficient of variation up to $50 \%$ (test $\mathrm{n}^{\circ} 1$ ) and $100 \%$ (test $\mathrm{n}^{\circ} 2$ ), depending on how similar the soils are. Test $\mathrm{n}^{\circ} 3$ has shown that the percentage difference between the site-specific soil and its more similar default soil (SOIL6) can be up to $500 \%$. Therefore, from the point of view of LCA practitioners, the outcomes showed that the application of detailed soil characteristics in PestLCI 2.0 results in a very comprehensive calculation of pesticide emissions in the different compartments, which is relevant for the LCI phase. This however is achieved at the expenses of an increased data collection and elaboration of detailed information on site-specific soil characteristics, which requires a specific expertise in soil science where no data are available. Moreover, the distribution among the environmental compartments greatly depends also on chemical-physical characteristics of the active 
ingredients. In light of these observations, fixed percentage distributions frequently used in literature appear not to be appropriate for every type of pesticide and for every type of soil.

From the point of view of LCIA method developers, it is remarkable that, regardless of the soil profile, about $10-30 \%$ of some active ingredients reaches groundwater. Therefore, in order to exploit the detailed results of PestLCI 2.0 in the impact assessment phase, the development of characterization factors for pollutant emitted to groundwater seems crucial to improve LCA results. Furthermore, the study highlighted some important features related to how soil characteristics are dealt with in the model, which provides insights for improving PestLCI 2.0. The assumption that the ratio between slow mobile macropores and fast mobile macropores is the same in all types of soil (0.7 and 0.3 , respectively) is a strong simplification and it does not reflect the reality. Scientific literature reports that macropores occur more in structured soils (clayey and silty soils) and less in destructured soils (sandy soil) (Hall, 1993), This assumption of PestLCI 2.0 modifies the speed of water in sandy soil and the role of macropores in the emission to groundwater. It would be advantageous to set the fraction of macropores to the soil type as a function of their clay, silt and sand content. Another important feature is that the model considers only the top 1 meter depth of soil. This assumption is based on two motivations. Firstly, PestLCI 2.0 assumes that the field below 1 meter is not manipulated by agricultural practice; therefore 1 meter is considered sufficiently deep to draw the line between the technosphere and the ecosphere. Secondly, PestLCI 2.0 assumes that pesticide degradation stops below 1 meter, so that once a pesticide reaches $1 \mathrm{~m}$ of depth, it will at some point reach the groundwater. Therefore, the exact depth of water table is not considered. However, in locations where the water table is at a depth $<1 \mathrm{~m}$ (i.e. coastal or spring areas), this assumption could be misleading. Our final observation is that PestLCI 2.0 considers organic horizons as mineral horizons. In the model, organic carbon is only used to calculate the fraction of pesticide sorbed and the density of the soil horizon. This simplification could be another limitation in the case of soils with a high level of organic carbon, because in such horizons organic carbon has 
an important role especially in the downward movement of water and substances. Likewise, PestLCI 2.0 does not take into account the presence of rock fragments (i.e. soil skeleton $>2 \mathrm{~mm}$ ) in the calculation of emissions to surface and groundwater. This might be considered for future model updates.

In conclusion, the combination of detailed inventory data provided by PestLCI 2.0 using sitespecific data and characterisation factors for groundwater emission, combined with future improvements of the model would result in a comprehensive evaluation of pesticide emissions at inventory level and of their environmental impacts, thus representing a fundamental step for increasing the knowledge about the behaviour of substances in a life cycle perspective.

\section{Acknowledgments}

The authors are grateful for the financial support provided by the Project AGRICARE (LIFE13 ENV/IT/000583), and to all the partners, who provided the data on pesticides elaborated for the application of PestLCI 2.0. Authors would like also to thank Prof. Andrea Pasteris from University of Bologna for his contribution to the statistical evaluations performed in the work.

\section{List of acronyms}

ARPAV = Veneto Regional Agency for Environmental Prevention and Protection

BIB1 = Bibione soil

C=clay

CAB1 $=$ Caberlotto soil

CAP1 $=$ Capitello soil

$\mathrm{CFO} 1=\mathrm{Ca}$ Fornera soil

CMT $=$ Meteorological Centre of Teolo 
CON1 $=$ Conche soil

CRL1 = Caorle soil

CTU1 $=$ Ca' Turcata soil

$\mathrm{L}=$ loam

LCA $=$ Life Cycle Assessment

LCIA = Life Cycle Impact Assessment

LS=loamy sand

MEL1 = Casa Scaramello soil

PEFCR $=$ Product Environmental Footprint Category Rules

QUA1 = Quarto d'Altino soil

$\mathrm{S}=$ sand

SAB1 $=$ Sabbioni soil

$\mathrm{SCL}=$ sandy clay loam

SCO1 = Santa Scolastica soil

SIC $=$ silty clay

SICL=silty clay loam

SIL=silt loam

$\mathrm{SL}=$ sandy loam

SOIL6 = Default soil from PestLCI 2.0 database

STU = Soil Typological Units

TDF1 $=$ Torre di Fine soil

VAD1 = Valcerere Dolfina soil

VAN1 = Vanzo soil

VED1 = Casa Vendramin soil 


\section{REFERENCES}

- $\quad$ Alletto, L., Benoit, P., Bergheaud, V., Coquet, Y., 2008. Temperature and water pressure head effects on the degradation of the diketonitrile metabolite of isoxaflutole in a loamy soil under two tillage systems. Environ. Pollut. 156:678-688. doi: 10.1016/j.envpol.2008.06.026.

- ARPAV, 2018a. Carta dei suoli del Veneto (in Italian). Available at: www.arpa.veneto.it/suolo/htm/carte_web.asp (last visit: July 30th, 2018)

- ARPAV, 2018b. Climatologia (in Italian). Available at: www.arpa.veneto,it/temiambientali/climatologia/dati (last visit July 30th, 2018)

- Audsley, A., Alber, S., Clift, R., Cowell, S., Crettaz, P., Gaillard, G., Hausheer, J., Jolliet, O., Kleijn, R., Mortensen, B., Pearce, D., Roger, E., Teulon, H., Weidema, B., van Zeijts, H., 1997. Harmonisation of Environmental Life Cycle Assessment for Agriculture. Final Report for Concerted Action AIR3-CT94-2028. Silsoe Research Institute, Silsoe, UK, pp. 103.

- Bacenetti, J., Fusi, A., Negri, M., Guidetti, R., Fiala, M., 2014. Environmental assessment of two different crop systems in terms of biomethane potential production. Sci. Total Environ. 466-467:1066-1077 (ISSN: 0048-9697). 10.1016/j.scitotenv.2013.07.109.

- Bacenetti, J., Fusi, A., Negri, M., Fiala, M., 2015. Impact of cropping system and soil tillage on environmental performance of cereal silage productions. J. Clean. Prod. 86:49-59 (ISSN: 09596526). 10.1016/j.jclepro.2014.08.052.

- Birkved, M., Hauschild, M.Z., 2006. PestLCI: A model for estimating field emissions of pesticides in agricultural LCA. Ecol. Modell. 198(3-4): 433-451. doi:10.1016/j.ecolmodel.2006.05.035.

- Damalas C.A., Eleftherohorinos I.G., 2011. Pesticide Exposure, Safety Issues, and Risk Assessment Indicators. Int. J. Environ. Res. Public Health, 8(5), 1402-1419; doi:10.3390/ijerph8051402. 
- Dechesne, A., Badawi, N., Aamand, J., Smets, B.F., 2014. Fine scale spatial variability of microbial pesticide degradation in soil: scales, controlling factors, and implications. Front. Microbiol., Vol. 5, Article 667, 1-14. doi: 10.3389/fmicb.2014.00667.

- Dijkman, T.J., Birkved, M., Hauschild, M.Z., 2012. PestLCI 2.0: a second generation model for estimating emissions of pesticides from arable land in LCA. Int. J. Life Cycle Assess. 17(8): 973-986. doi:10.1007/s11367-012-0439-2.

- Dijkman, T.J., Birkved, M., Saxe, H., Wenzel, H., Hauschild, M.Z., 2017. Environmental impacts of barley cultivation under current and future climatic conditions. J. Clean. Prod. 140:644-653. http://dx.doi.org/10.1016/j.jclepro.2016.05.154.

- European Commission, 2001.White Paper - Strategy for a future Chemicals Policy. COM (2001) 88 final, Brussels, February 27 2001. http://europa.eu.int/comm/environment/chemicals/tstimp_en.htm

- European Commission, 2017. PEFCR Guidance document, Guidance for the 13 development of Product Environmental Footprint Category Rules (PEFCRs), version 6.3, December 14 2017.

- Fantin, V., Righi, S., Rondini, I., Masoni, P., 2017. Environmental assessment of wheat and maize production in an Italian farmers' cooperative. J. Clean. Prod. 140:631-643.

- FAO/ISRIC/ISSS, 1998. World Reference Base for Soil Resources. World Soil Resources Report, \#84. FAO, Rome, 88 pp.Finley, S.D., Broadbelt, L.J., Hatzimanikatis, V., 2010. In silico feasibility of novel biodegradation pathways for 1,2,4-trichlorobenzene. BMC Syst. Biol. $4: 4-14$.

- Goedkoop, M., 1995. Eco-indicator 95, weighting method for environmental effects that damage ecosystems or human health on a European scale, Final report, National Institute of Public Health and Environmental Protection (RIVM), Bilthoven, The Netherlands, pp. 85. 
- Goedkoop, M., Müller-Wenk, R., Hofstetter, P., Spriensma, R., 1998. The Eco-Indicator 99 Explained. Int. J. Life Cycle Assess. 3(6):352-360.

- Goglio, P., Grant, B.B., Smith, W.N., Desjardins, R.L., Worth, D.E., Zentner, R., Malhi, S.S., 2014. Impact of management strategies on the global warming potential at the cropping system level. Sci. Total Environ. 490:921-933. http://dx.doi.org/10.1016/j.

- Hall, D.G.M.,1993. An amended functional leaching model applicable to structured soils. I. Model description. J Soil Sci 44, 579-588.

- Heijungs, R., Guinée, J.B., Huppes, G., Lankreijer, R.M., Udo de Haes, H.A., Wegner, Sleeswijk, A., Ansems, A.M.M., Eggels, P.G., van Duin R., Goede, A.P., 1992. Environmental life cycle assessment of products, background and guide. Centre of Environmental Science (CML), NL-2300 RA Leiden, The Netherlands, pp. 130.

- Holterman, H.J., Van de Zande, J.C., 2003. IMAG drift calculator v1.1: User manual. Retrieved from http://www.toxswa.pesticidemodels.eu/download/IDCmanual.pdf (July 29, 2011).

- Huijbregts, M.A.J., Thissen, U., Guinée, J.B., Jager, T., Kalf, D., van de Meent, D., Ragas, A.M.J., Wegener Sleeswijk, A., Reijnders, L., 2000. Priority assessment of toxic substances in life cycle assessment. Part I: calculation of toxicity potentials for 181 substances with the nested multi-media fate, exposure and effects model USES-LCA. Chemosphere 41: 541-573.

- IEA Bioenergy, 2015. Modeling potential freshwater ecotoxicity impacts due to pesticide use in biofuel feedstock production. The cases of maize, rapeseed, Salix, soybean, sugarcane and wheat. IEA Bioenergy Task 43, Report 2015: TR04.

- Jury, W.A., Focht, D.D., Spencer, W.J., 1987. Evaluation of pesticide groundwater pollution from standard indices of soil-chemical adsorption and biodegradation. J. Environ. Qual. 10, $422-428$. 
- Kramer, K.J., 2003. Life Cycle Assessment of vegetable products. In: Environmentally-friendly food processing. Editors: Mattsson, B. and Sonesson U. CRC Press, Washington DC, USA.

- $\quad$ Lauber, C.L., Hamady, M., Knight, R., Fierer, N., 2009. Pyrosequencing based assessment of soil $\mathrm{pH}$ as a predictor of soil bacterial community structure at the continental scale. Appl. Environ. Microbiol. 75:5111-5120. doi: 10.1128/AEM.00335-09.

- Leonard, R.A., Kinsel, E.G., Still, D.A., 1987. GLEAMS: groundwater loading effects of agricultural management systems. Transact. ASAE 30 (5), 1403-1418

- Margni M., Rossier D., Crettaz P., Jolliet O., 2002. Life cycle impact assessment of pesticides on human health and ecosystems. Agr. Ecosyst. Environ.93: 379-392.

- Nemecek, T., Erzinger, S., 2005. Modelling Representative Life Cycle Inventories for Swiss Arable Crops. Int J Life Cycle Assess. 10 (1) 1 -9.

- Nemecek, T., Kägi, T., 2007. Life Cycle Inventories of Swiss and European Agricultural Production Systems. Ecoinvent final report v2.0, no. 15, Agroscope Reckenholz-Taenikon Research Station ART. Swiss Centre for Life Cycle Inventories, Zurich and Dübendorf, Switzerland.

- Nielsen, M.H., Styczen, M., Ernstsen, V., Petersen, C.T., and Hansen, S., 2010. Field study of preferential flow pathways in and between drain trenches. Vadose Zone J. 9:1073. doi:10.2136/vzj2010.0013.

- Niero, M., Ingvordsen, C.H., Jørgensen, R.B., Hauschild, M.Z., 2015a. How to manage uncertainty in future Life Cycle Assessment (LCA) scenarios addressing the effect of climate change in crop production. J. Clean. Prod. 107:693-706. http://dx.doi.org/10.1016/j. jclepro.2015.05.061. 
- $\quad$ Niero, M., Ingvordsen, C.H., Peltonen-Sainio, P., Jalli, M., Lyngkjær, M.F., Hauschild, M.Z., Jørgensen, R.B., 2015b. Eco-efficient production of spring barley in a changed climate: a life cycle assessment including primary data from future climate scenarios. Agric. Syst. 136:46-60. http://dx.doi.org/10.1016/j.agsy.2015.02.007.

- Notarnicola B., Tassielli G., Renzulli P.A., Lo Giudice A., 2015. Life Cycle Assessment in the agri-food sector: an overview of its key aspects, international initiatives, certification, labelling schemes and methodological issues, in: Notarnicola, B., Salomone, R., Petti, L., Renzulli, P.A., Roma, R., Cerutti, A.K. (Eds.), Life cycle Assessment in the Agri-food Sector - Case studies, Methodological Issues and Best Practices. Springer International Publishing, Switzerland, pp. $1-56$.

- Notarnicola, B., Sala, S., Anton, A., McLaren, S.J., Saouter, E., Sonesson, U., 2017. The role of life cycle assessment in supporting sustainable agri-food systems: a review of the challenges. J. Clean. Prod. 140:399-409.

- Park, J.H., Feng, Y., Ji, P., Voice, T.C., Boyd, S.A., 2003. Assessment of bioavailability of soil-sorbed atrazine. Appl. Environ. Microbiol. 69:3288-3298.

- Rasmussen, J., Aamand, J., Rosenberg, P., Jacobsen, O.S., Sørensen, S.R., 2005. Spatial variability in the mineralization of the phenylurea herbicide linuron within a Danish agricultural field: multivariate correlation to simple soil parameters. Pest Manag. Sci. 61:829837. doi: $10.1002 /$ ps.1041.

- Renaud-Gentié, C., Dijkman, T.J., Bjørn, A., Birkved, M., 2015. Pesticide emission modelling and freshwater ecotoxicity assessment for Grapevine LCA: adaptation of PestLCI 2.0 to viticulture. Int. J. Life Cycle Assess. 20:1528-1543. doi: 10.1007/s11367-015-0949-9

- $\quad$ Rosenbaum, R.K., Anton, A., Bengoa, X., Bjørn, A., Brain, R., Bulle, C., Cosme, N., Dijkman, T.J., Fantke, P., Felix, M., Geoghegan, T.S., Gottesbüren, B., Hammer, C., Humbert, S., Jolliet, 
O., Juraske, R., Lewis, F., Maxime, D., Nemecek, T., Payet, J., Räsänen, K., Roux, P., Schau, E.M., Sourisseau, S., van Zelm, R., von Streit, B., Wallman, M., 2015. The Glasgow consensus on the delineation between pesticide emission inventory and impact assessment for LCA. Int. J. Life Cycle Assess. 20:765-776. Doi: 10.1007/s11367-015-0871-1

- Rosenbaum, R.K., Bachmann, T.K., Gold, L.S., Huijbregts, M.A.J., Jolliet, O., Juraske, R., Koehler, A,, Larsen, H.F., MacLeod, M., Margni, M., McKone, T.E., Payet, J., Schuhmacher, M., Van de Meent, D., Hauschild, M.Z., 2008. USEtox: The UNEP/SETAC-consensus model: recommended characterisation factors for human toxicity and freshwater ecotoxicity in life cycle impact assessment. Int. J. Life Cycle Assess. 13 (7):532-546

- Schmidt Rivera, X.C., Bacenetti, J., Fusi, A., Niero, M., 2017. The influence of fertiliser and pesticide emissions model on life cycle assessment of agricultural products: The case of Danish and Italian barley. Sci. Total Environ. 592: 745-757. doi: 10.1016/j.scitotenv.2016.11183

- Shakoori, A.R., Makhdoom, M., Haq, R.U., 2000. Hexavalent chromium reduction by a ichromate-resistant gram-positive bacterium isolated from effluents of tanneries. Appl. Microbiol. Biot. 53:348-351.

- Soil Survey Staff, 1998. Keys to soil taxonomy, $8^{\text {th }}$ ed., United States Department of Agriculture, Natural Resources Conservation Service.

- Verna, J.P., Jaiswal, D.K., Sagar, R., 2014. Pesticide relevance and their microbial degradation: a-state-of-art. Rev. Environ. Sci. Biotechnol. 13:429-466. doi: 10.1007/s11157-014-9341-7.

- Vinther, F.P., Brinch, U.C., Elsgaard, L., Fredslund, L., Iversen, B.V, Torp, S., Jacobsen, C.S., 2008. Field-scale variation in microbial activity and soil properties in relation to mineralization and sorption of pesticides in a sandy soil. J. Environ. Qual. 37:1710-1718. doi:10.2134/jeq2006.0201. 
Table 1. Summary characteristics of considered soils (Source: assembled from ARPAV, 2018a).

\begin{tabular}{|c|c|c|c|c|c|c|c|c|c|}
\hline Soil Typological Unit (STU) & TDF1 & CTU1 & SCO1 & CAB1 & CFO1 & CON1 & BIB1 & QUA1 & CRL1 \\
\hline Soil Name & Torre di Fine & Ca' Turcata & Santa Scolastica & Caberlotto & $\mathrm{Ca}^{\prime}$ Fornera & Conche & Bibione & Quarto d'Altino & Caorle \\
\hline $\begin{array}{l}\text { Keys to Soil Taxonomy } \\
\text { (SSS, 1998) }\end{array}$ & $\begin{array}{c}\text { Fluvaquentic } \\
\text { Eutrudepts } \\
\text { fine-silty, } \\
\text { carbonatic, } \\
\text { mesic }\end{array}$ & $\begin{array}{l}\text { Fluvaquentic } \\
\text { Eutrudepts } \\
\text { fine, mixed, } \\
\text { mesic }\end{array}$ & $\begin{array}{l}\text { Fluvaquentic } \\
\text { Endoaquepts } \\
\text { fine, mixed, } \\
\text { calcareous, } \\
\text { mesic }\end{array}$ & $\begin{array}{c}\text { Typic } \\
\text { Endoaquepts } \\
\text { fine-silty, } \\
\text { mixed, mesic }\end{array}$ & $\begin{array}{l}\text { Oxyaquic } \\
\text { Eutrudepts } \\
\text { fine-silty, } \\
\text { carbonatic, } \\
\text { mesic }\end{array}$ & $\begin{array}{c}\text { Oxyaquic } \\
\text { Udifluvents } \\
\text { coarse-loamy, } \\
\text { mixed, } \\
\text { calcareous, } \\
\text { mesic }\end{array}$ & $\begin{array}{c}\text { Fluvaquentic } \\
\text { Eutrudepts } \\
\text { coarse-silty, } \\
\text { carbonatic, } \\
\text { mesic }\end{array}$ & $\begin{array}{l}\text { Oxyaquic } \\
\text { Eutrochrepts } \\
\text { fine-silty, } \\
\text { mixed, mesic }\end{array}$ & $\begin{array}{l}\text { Oxyaquic } \\
\text { Udifluvents } \\
\text { coarse-silty, } \\
\text { carbonatic, } \\
\text { mesic }\end{array}$ \\
\hline $\begin{array}{l}\text { World Reference Base (FAO, } \\
\text { 1998) }\end{array}$ & $\begin{array}{c}\text { Gleyic Fluvic } \\
\text { Cambisols } \\
\text { (Hypercalcaric) }\end{array}$ & $\begin{array}{c}\text { Gleyic Fluvic } \\
\text { Cambisols } \\
\text { (Calcaric) }\end{array}$ & $\begin{array}{l}\text { Calcaric } \\
\text { Hypocalcic } \\
\text { Gleysols }\end{array}$ & $\begin{array}{l}\text { Calcaric Hum } \\
\text { Gleysols }\end{array}$ & $\begin{array}{c}\text { Gleyic Fluvic } \\
\text { Cambisols } \\
\text { (Hypercalcaric) }\end{array}$ & $\begin{array}{l}\text { Calcaric } \\
\text { Fluvisols }\end{array}$ & $\begin{array}{c}\text { Humic } \\
\text { Endogleyc } \\
\text { Fluvisols } \\
\text { (Hypercalcaric) } \\
\end{array}$ & $\begin{array}{l}\text { Calcaric Fluvic } \\
\text { Cambisols }\end{array}$ & $\begin{array}{c}\text { Hypercalcaric } \\
\text { Endogleyic } \\
\text { Fluvisols }\end{array}$ \\
\hline Horizon sequence & $\mathrm{Ap} / \mathrm{Bg} / \mathrm{Cg}$ & $\mathrm{Ap} / \mathrm{Bg} /(\mathrm{Ha}) / \mathrm{Cg}$ & $\mathrm{Ap} / \mathrm{B}(\mathrm{k}) \mathrm{g} / \mathrm{Cg}$ & $\mathrm{Ap} / \mathrm{Bg} / \mathrm{Cg} /(\mathrm{Ha})$ & $\mathrm{Ap} / \mathrm{Bg} / \mathrm{Cg}$ & $\mathrm{Ap} / \mathrm{C} / \mathrm{Cg}$ & $\mathrm{Ap} / \mathrm{Bg} / \mathrm{Cg}$ & $\mathrm{Ap} / \mathrm{Bg} / \mathrm{Cg}$ & $\mathrm{Ap} / \mathrm{Cg}$ \\
\hline Soil type & SICL & SICL & SICL & SICL & SICL & SIL & SIL & SIL & SIL \\
\hline Horizon designation & Ap1 & Ap1 & Ap & Ap & Ap1 & Ap & Ap1 & Ap1 & Ap1 \\
\hline Start depth $(\mathrm{cm})$ & 0 & 0 & 0 & & 0 & 0 & 0 & 0 & 0 \\
\hline End depth $(\mathrm{cm})$ & 40 & 20 & 50 & 50 & 40 & 50 & 30 & 40 & 30 \\
\hline Clay content $(<2 \mu \mathrm{m})(\%)$ & 25.1 & 33.4 & 32 & 40.2 & 31 & 22.3 & 19 & 23.2 & 17.6 \\
\hline Silt content $(2-50 \mu \mathrm{m})(\%)$ & 59.8 & 19.8 & 51.1 & 59.2 & 62.2 & 59 & 67.9 & 55.4 & 70.9 \\
\hline Sand content $(>50 \mu \mathrm{m})(\%)$ & 15.1 & 46.8 & 16.9 & 0.6 & 6.8 & 18.7 & 13.1 & 21.3 & 11.5 \\
\hline Organic carbon $(\%)$ & 1.4 & 2.3 & 1.1 & 1 & 1.2 & 0.6 & 1.2 & 0.8 & 0.8 \\
\hline $\mathrm{pH}$ & 8.3 & 8 & 8 & 8.1 & 8.2 & 8.2 & 8.1 & 7.9 & 8.2 \\
\hline Soil type & SIL & SCL & SICL & SIC & SICL & SIL & SIL & SIL & SIL \\
\hline Horizon designation & Ap2 & Ap2 & $\mathbf{A b}$ & Bg1 & Ap2 & $\mathbf{C 1}$ & Ap2 & Ap2 & Ap2 \\
\hline Start depth $(\mathrm{cm})$ & 40 & 20 & 50 & 50 & 40 & 50 & 30 & 40 & 30 \\
\hline End depth $(\mathrm{cm})$ & 55 & & 80 & 75 & 70 & 60 & 55 & 70 & 55 \\
\hline Clay content $(<2 \mu \mathrm{m})(\%)$ & 25.8 & 38.4 & 52.8 & 30.5 & 30.8 & 17.8 & 18.3 & 22 & 17.5 \\
\hline Silt content $(2-50 \mu \mathrm{m})(\%)$ & 61.5 & 57.1 & 39.4 & 69.1 & 62 & 60.7 & 69.2 & 53.9 & 71.6 \\
\hline Sand content $(>50 \mu \mathrm{m})(\%)$ & 12.7 & 4.5 & 7.8 & 0.3 & 7.2 & 21.5 & 12.5 & 24.1 & 10.9 \\
\hline Organic carbon $(\%)$ & 1.5 & 2.1 & 1.4 & 0.9 & 1.4 & 0.6 & 1.1 & 1.4 & 0.6 \\
\hline & 8.2 & 7.9 & 8 & 8.2 & 8.2 & 8.3 & 8.1 & 7.9 & 8.2 \\
\hline Soil type & SIL & SICL & $\mathrm{C}$ & SICL & SICL & SIL & SIL & SIL & SIL \\
\hline Horizon designation & Bg1 & $\mathbf{B g}$ & Bkg & Bg2 & Bg1 & $\mathrm{C2}$ & $\mathrm{Bg}$ & Bw & Cg1 \\
\hline Start depth $(\mathrm{cm})$ & 55 & 60 & 80 & 75 & 70 & 60 & 55 & 70 & 55 \\
\hline End depth $(\mathrm{cm})$ & 85 & 105 & 105 & 120 & 100 & 90 & 85 & 105 & 90 \\
\hline
\end{tabular}




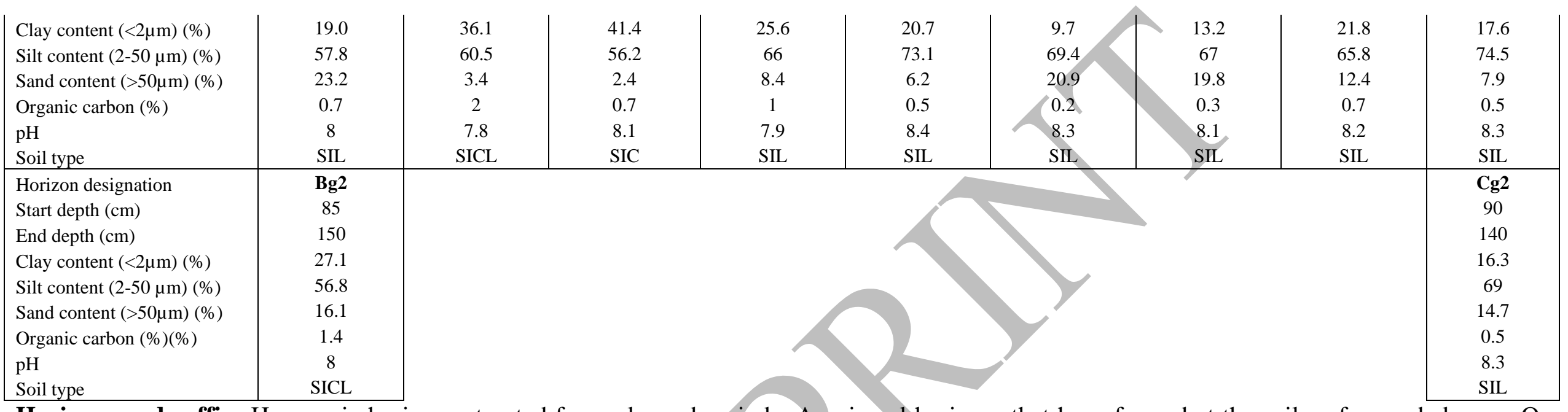

Horizons and suffix: $\mathrm{H}=$ organic horizon saturated for prolonged periods; $\mathrm{A}=$ mineral horizons that have formed at the soil surface or below an $\mathrm{O}$ horizon; $\mathrm{B}=$ mineral horizons that have formed below an $\mathrm{A}, \mathrm{E}$, or $\mathrm{O}$ horizon; $\mathrm{C}=$ mineral horizons or layers that are little affected by pedogenic processes and lack the properties of $\mathrm{O}, \mathrm{A}, \mathrm{E}, \mathrm{B}$, or L horizons; $\mathrm{p}=$ tillage or other disturbance; $\mathrm{b}=$ buried genetic horizon; $\mathrm{g}=\mathrm{strong}$ gleying; $\mathrm{k}=$ accumulation of secondary carbonates; $\mathrm{w}=$ development of color or structure.

Soil type: $\mathrm{C}=$ clay; SIC=silty clay; SICL=silty clay loam; SIL=silt loam; L=loam; SCL=sandy clay loam; SL=sandy loam; LS=loamy sand; S=sand. 
Table 2. Summary characteristics of considered soils (Source: assembled from ARPAV, 2018a).

\begin{tabular}{|c|c|c|c|c|c|c|c|}
\hline $\begin{array}{lll}\begin{array}{l}\text { Soil } \\
\text { (STU) }\end{array} & \text { Typological } & \text { Unit } \\
\end{array}$ & VAN1 & VED1 & MEL1 & CAP1 & SAB1 & VAD1 & SOIL6 \\
\hline Soil Name & Vanzo & Casa Vendramin & Casa Scaramello & Capitello & Sabbioni & Valcerere Dolfina & PestLCI 2.0 database \\
\hline $\begin{array}{l}\text { Keys to Soil Taxonomy } \\
\text { (SSS, 1998) }\end{array}$ & $\begin{array}{l}\text { Typic Calciustepts } \\
\text { coarse-loamy, } \\
\text { mixed, mesic }\end{array}$ & $\begin{array}{c}\text { Oxyaquic } \\
\text { Haplustepts fine- } \\
\text { loamy,mixed, mesic }\end{array}$ & $\begin{array}{c}\text { Typic Calciustepts } \\
\text { coarse-loamy over } \\
\text { sandy or sandy-skeletal, } \\
\text { mixed, mesic }\end{array}$ & $\begin{array}{c}\text { Typic } \\
\text { Ustipsamment } \\
\text { s, mixed, } \\
\text { mesic }\end{array}$ & $\begin{array}{c}\text { Oxyaquic } \\
\text { Ustipsamments } \\
\text { sandy, mixed, } \\
\text { mesic } \\
\end{array}$ & $\begin{array}{l}\text { Typic Ustipsamments } \\
\text { sandy, mixed, mesic }\end{array}$ & \\
\hline $\begin{array}{l}\text { World Reference } \\
\text { (FAO, 1998) }\end{array}$ & $\begin{array}{l}\text { Hypocalcic } \\
\text { Calcisols }\end{array}$ & Calcaric Cambisols & Hypercalcic Calcisols & $\begin{array}{c}\text { Calcaric } \\
\text { Regosols }\end{array}$ & $\begin{array}{l}\text { Calcaric Arenic } \\
\text { Fluvisols }\end{array}$ & Eutric Arenosols & \\
\hline Horizon sequence & $\mathrm{Ap} / \mathrm{Bw} /(\mathrm{Bk}) / \mathrm{C}$ & $\mathrm{Ap} / \mathrm{Bw} / \mathrm{C}(\mathrm{g})$ & $\mathrm{Ap} / \mathrm{B}(\mathrm{k}) / \mathrm{C}$ & $\mathrm{Ap} / \mathrm{C}$ & $\mathrm{Ap} / \mathrm{C}$ & $\mathrm{Ap} / \mathrm{C}$ & \\
\hline Soil type & $\mathrm{L}$ & $\mathrm{L}$ & $\mathrm{L}$ & SL & $\mathrm{S}$ & $S$ & \\
\hline Horizon designation & Ap & Ap & Ap & Ap & Ap & Ap & \\
\hline Start depth $(\mathrm{cm})$ & 0 & 0 & 0 & & 0 & 0 & 0 \\
\hline End depth $(\mathrm{cm})$ & 55 & 50 & 60 & 55 & 50 & 30 & 27 \\
\hline Clay content $(<2 \mu \mathrm{m})(\%)$ & 19.4 & 19 & 11.9 & 10.8 & 3.6 & 1.1 & 34 \\
\hline Silt content $(2-50 \mu \mathrm{m})(\%)$ & 46.6 & 37 & 29.1 & 26.1 & 9.1 & 2.4 & 59 \\
\hline Sand content $(>50 \mu \mathrm{m})(\%)$ & 34 & 44 & 59 & 63.1 & 87.3 & 96.5 & 7 \\
\hline Organic carbon (\%) & 0.8 & 1.3 & 0.4 & 0.6 & 1 & 0.2 & 1.8 \\
\hline $\mathrm{pH}$ & 8.2 & 8.2 & 8.2 & 8.2 & 7.8 & 8.3 & 6.6 \\
\hline Soil type & $\mathrm{L}$ & $\mathrm{L}$ & SL & SL & $S$ & $\mathrm{~S}$ & SICL \\
\hline Horizon designation & $\mathbf{B k}$ & Bw & Bk & C1 & $\mathbf{C}$ & C1 & \\
\hline Start depth $(\mathrm{cm})$ & 55 & 50 & 60 & 55 & 50 & 30 & 27 \\
\hline End depth $(\mathrm{cm})$ & 75 & & 85 & 100 & 95 & 60 & 47 \\
\hline Clay content $(<2 \mu \mathrm{m})(\%)$ & 19.2 & 17.8 & 7.4 & 3.6 & 4 & 0.1 & 37 \\
\hline Silt content $(2-50 \mu \mathrm{m})(\%)$ & 50.7 & 48.5 & 55 & 3.1 & 13.5 & 1.4 & 55 \\
\hline Sand content $(>50 \mu \mathrm{m})(\%)$ & 30.1 & 33.7 & 37.7 & 93.3 & 82.5 & 98.5 & 8 \\
\hline Organic carbon $(\%)$ & 0.5 & & 0.3 & 0 & 0.8 & 0 & 1.8 \\
\hline $\mathrm{pH}$ & 8.2 & 8.2 & 8.4 & 8.7 & 8.1 & 8.4 & 6.9 \\
\hline Soil type & SIL & $\mathrm{L}$ & SIL & $\mathrm{S}$ & SF & $\mathrm{S}$ & SICL \\
\hline Horizon designation & C1 & $\mathbf{A b}$ & $\mathbf{C}$ & & $\mathrm{Cg}$ & $\mathrm{C2}$ & \\
\hline Start depth $(\mathrm{cm})$ & & & 85 & & 95 & 60 & 47 \\
\hline End depth $(\mathrm{cm})$ & 130 & 130 & 100 & & 150 & 120 & 63 \\
\hline Clay content $(<2 \mu \mathrm{m})(\%)$ & 4.4 & 25.8 & 2.2 & & 12.9 & 0 & 39 \\
\hline Silt content $(2-50 \mu \mathrm{m})(\%)$ & 22 & 66.2 & 8.4 & & 46.2 & 0.9 & 55 \\
\hline Sand content $(>50 \mu \mathrm{m})(\%)$ & 73.6 & 8 & 89.4 & & 40.9 & 99.1 & 6 \\
\hline
\end{tabular}




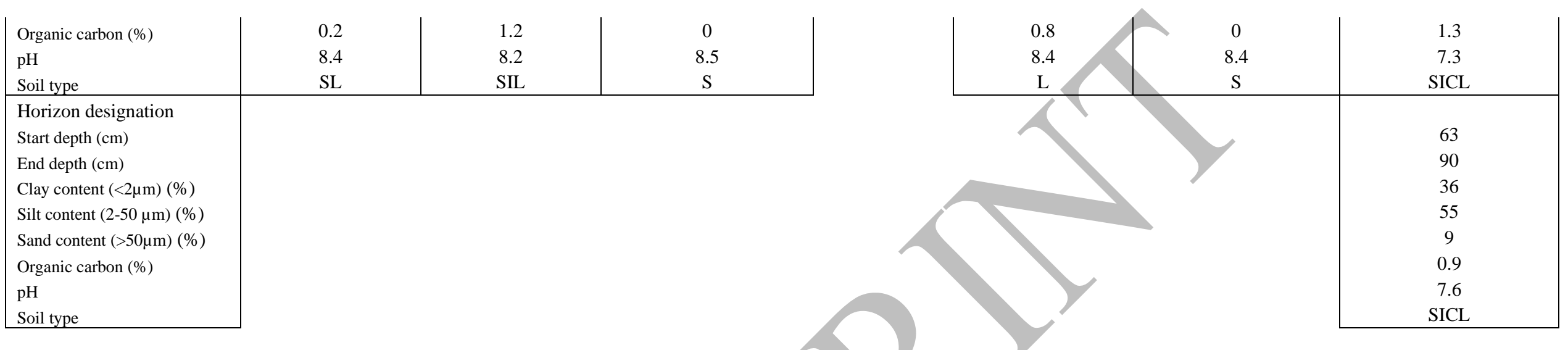

Horizons and suffix: $\mathrm{H}=$ organic horizon saturated for prolonged periods; $\mathrm{A}=$ mineral horizons that have formed at the soil surface or below an $\mathrm{O}$ horizon; $\mathrm{B}=$ mineral horizons that have formed below an $\mathrm{A}$, $\mathrm{E}$, or $\mathrm{O}$ horizon; $\mathrm{C}=$ mineral horizons or layers that are little affected by pedogenic processes and lack the properties of $\mathrm{O}, \mathrm{A}, \mathrm{E}, \mathrm{B}$, or L horizons; $\mathrm{p}=$ tillage or other disturbance; $\mathrm{b}=$ buried genetic horizon; $\mathrm{g}=\mathrm{strong}$ gleying; $\mathrm{k}=$ accumulation of secondary carbonates; $\mathrm{w}=$ development of color or structure.

Soil type: C=clay; SIC=silty clay; SICL=silty clay loam; SIL=silt loam; L=loam; SCL=sandy clay loam; SL=sandy loam; LS=loamy sand; S=sand. 
Table 3. Quantity and type of pesticide applied for maize cultivation on the Vallevecchia experimental farm (Source: AGRICARE Project). Pesticide hazard codes and classes: H302-Acute toxicity, oral; H317-Sensitisation, skin; H373-Specific target organ toxiticy, repeated exposure; H400-Hazardous to the aquatic environment, acute hazard; H410- Hazardous to the aquatic environment, long-term hazard (Regulation EC 1272/2008). Data refer to maize productive cycle of one year.

\begin{tabular}{|l|c|c|}
\hline Type of treatment & & Hazard codes \\
\hline Pre-emergence & & \\
\hline Terbuthylazine (L/ha) & 0.81 & $\mathrm{H} 302, \mathrm{H} 373, \mathrm{H} 400, \mathrm{H} 410$ \\
\hline Metolachlor (L/ha) & 1.13 & $\mathrm{H} 317$ \\
\hline Post-emergence & & \\
\hline Terbuthylazine (L/ha) & 0.77 & $\mathrm{H} 302, \mathrm{H} 373, \mathrm{H} 400, \mathrm{H} 410$ \\
\hline Metolachlor (L/ha) & 1.07 & $\mathrm{H} 317$ \\
\hline Treatment for insects & & \\
\hline Cypermethrin (kg/ha) & 0.018 & $\mathrm{H} 400, \mathrm{H} 410$ \\
\hline Water for irrigation (mm) & 111 & \\
\hline
\end{tabular}


Table 4. Distributions of pesticide among the environmental compartments obtained with Pest LCI 2.0 model and using site-specific data (TDF1) and those obtained applying data of soils with similar characteristics. Figures indicate the fraction of pesticide emitted in each environmental compartment.

\begin{tabular}{|c|c|c|c|c|c|c|c|c|c|c|c|c|c|c|}
\hline Terbuthylazine (pre-emergence) & TDF1 & CTU1 & SCO1 & CAB1 & CFO1 & CON1 & BIB1 & QUA1 & CRL1 & MIN & MAX & Average & Stand.Dev. & c.v.\% \\
\hline Emission to air (fraction) & $9.3 \mathrm{E}-02$ & $9.3 \mathrm{E}-02$ & $9.23 \mathrm{E}-02$ & $9.3 \mathrm{E}-02$ & $9.3 \mathrm{E}-02$ & $9.3 \mathrm{E}-02$ & $9.3 \mathrm{E}-02$ & 9.3E-02 & $9.3 \mathrm{E}-02$ & $9.3 \mathrm{E}-02$ & $9.3 \mathrm{E}-02$ & $9.3 \mathrm{E}-02$ & $7.2 \mathrm{E}-06$ & 0.0 \\
\hline $\begin{array}{l}\text { Emission to surface water or off-field } \\
\text { soil (fraction) }\end{array}$ & $1.1 \mathrm{E}-03$ & $1.3 \mathrm{E}-03$ & $1.1 \mathrm{E}-03$ & $1.3 \mathrm{E}-03$ & $1.3 \mathrm{E}-03$ & $1.3 \mathrm{E}-03$ & $1.3 \mathrm{E}-03$ & $1.3 \mathrm{E}-03$ & $1.3 \mathrm{E}-03$ & $1.1 \mathrm{E}-03$ & $1.3 \mathrm{E}-03$ & $1.2 \mathrm{E}-03$ & 7.7E-05 & 6.2 \\
\hline Emission to groundwater (fraction) & $3.0 \mathrm{E}-01$ & 3.0E-01 & $2.2 \mathrm{E}-01$ & 2.3E-01 & 2.7E-01 & $2.4 \mathrm{E}-01$ & $3.5 \mathrm{E}-01$ & 2.7E-01 & $3.4 \mathrm{E}-01$ & $2.2 \mathrm{E}-01$ & $3.5 \mathrm{E}-01$ & $2.8 \mathrm{E}-01$ & 4.6E-02 & 16.5 \\
\hline Degradation and uptake (fraction) & $6.1 \mathrm{E}-01$ & $6.1 \mathrm{E}-01$ & $6.8 \mathrm{E}-01$ & $6.8 \mathrm{E}-01$ & 6.4E-01 & $6.7 \mathrm{E}-01$ & $5.6 \mathrm{E}-01$ & $6.4 \mathrm{E}-01$ & $5.7 \mathrm{E}-01$ & $5.6 \mathrm{E}-01$ & $6.8 \mathrm{E}-01$ & $6.3 \mathrm{E}-01$ & $4.6 \mathrm{E}-02$ & 7.4 \\
\hline \multicolumn{15}{|l|}{ Terbuthylazine (post-emergence) } \\
\hline Emission to air (fraction) & $1.2 \mathrm{E}-01$ & $1.2 \mathrm{E}-01$ & $1.2 \mathrm{E}-01$ & $1.2 \mathrm{E}-01$ & 1.2E-01 & $1.2 \mathrm{E}-01$ & $1.2 \mathrm{E}-01$ & $1.2 \mathrm{E}-01$ & $1.2 \mathrm{E}-01$ & $1.2 \mathrm{E}-01$ & $1.2 \mathrm{E}-01$ & $1.2 \mathrm{E}-01$ & $3.3 \mathrm{E}-07$ & 0.0 \\
\hline $\begin{array}{l}\text { Emission to surface water or off-field } \\
\text { soil (fraction) }\end{array}$ & $1.3 \mathrm{E}-03$ & 1.3E-03 & $1.3 \mathrm{E}-03$ & $1.3 \mathrm{E}-03$ & $1.3 \mathrm{E}-03$ & $1.3 \mathrm{E}-03$ & $1.3 \mathrm{E}-03$ & $1.3 \mathrm{E}-03$ & $1.3 \mathrm{E}-03$ & $1.3 \mathrm{E}-03$ & $1.3 \mathrm{E}-03$ & $1.3 \mathrm{E}-03$ & $5.5 \mathrm{E}-11$ & 0.0 \\
\hline Emission to groundwater (fraction) & $1.7 \mathrm{E}-01$ & $1.8 \mathrm{E}-01$ & $1.6 \mathrm{E}-01$ & $2.3 \mathrm{E}-01$ & $2.2 \mathrm{E}-01$ & $1.8 \mathrm{E}-01$ & $1.6 \mathrm{E}-01$ & $2.2 \mathrm{E}-01$ & $1.6 \mathrm{E}-01$ & $1.6 \mathrm{E}-01$ & 2.3E-01 & $1.9 \mathrm{E}-01$ & $2.7 \mathrm{E}-02$ & 14.8 \\
\hline Degradation and uptake (fraction) & $7.1 \mathrm{E}-01$ & $7.0 \mathrm{E}-01$ & $7.2 \mathrm{E}-01$ & $6.5 \mathrm{E}-01$ & $6.6 \mathrm{E}-01$ & $7.0 \mathrm{E}-01$ & $7.2 \mathrm{E}-01$ & $6.6 \mathrm{E}-01$ & $7.2 \mathrm{E}-01$ & $6.5 \mathrm{E}-01$ & $7.2 \mathrm{E}-01$ & $6.9 \mathrm{E}-01$ & $2.7 \mathrm{E}-02$ & 4.0 \\
\hline \multicolumn{15}{|l|}{ Metolachlor (pre-emergence) } \\
\hline Emission to air (fraction) & 7.7E-05 & $2.7 \mathrm{E}-05$ & $1.0 \mathrm{E}-04$ & $1.2 \mathrm{E}-04$ & $8.7 \mathrm{E}-05$ & $2.9 \mathrm{E}-04$ & $8.7 \mathrm{E}-05$ & $2.0 \mathrm{E}-04$ & $1.8 \mathrm{E}-04$ & $2.7 \mathrm{E}-05$ & $2.9 \mathrm{E}-04$ & $1.3 \mathrm{E}-04$ & $7.9 \mathrm{E}-05$ & 59.5 \\
\hline $\begin{array}{l}\text { Emission to surface water or off-field } \\
\text { soil (fraction) }\end{array}$ & $9.5 \mathrm{E}-03$ & $9.4 \mathrm{E}-03$ & $9.5 \mathrm{E}-03$ & $9.5 \mathrm{E}-03$ & $9.5 \mathrm{E}-03$ & $9.6 \mathrm{E}-03$ & $9.5 \mathrm{E}-03$ & $9.6 \mathrm{E}-03$ & $9.6 \mathrm{E}-03$ & $9.4 \mathrm{E}-03$ & $9.6 \mathrm{E}-03$ & $9.5 \mathrm{E}-03$ & $4.8 \mathrm{E}-05$ & 0.5 \\
\hline Emission to groundwater (fraction) & $2.6 \mathrm{E}-03$ & $2.3 \mathrm{E}-03$ & $2.5 \mathrm{E}-03$ & 7.1E-03 & $5.3 \mathrm{E}-03$ & $4.6 \mathrm{E}-03$ & $2.5 \mathrm{E}-03$ & $6.2 \mathrm{E}-03$ & $3.3 \mathrm{E}-03$ & $2.3 \mathrm{E}-03$ & 7.1E-03 & $4.1 \mathrm{E}-03$ & $1.8 \mathrm{E}-03$ & 44.8 \\
\hline Degradation and uptake (fraction) & 9.9E-01 & $9.9 \mathrm{E}-01$ & $9.9 \mathrm{E}-01$ & $9.8 \mathrm{E}-01$ & 9.9E-01 & 9.9E-01 & 9.9E-01 & $9.8 \mathrm{E}-01$ & $9.9 \mathrm{E}-01$ & $9.8 \mathrm{E}-01$ & $9.9 \mathrm{E}-01$ & 9.9E-01 & $1.9 \mathrm{E}-03$ & 0.2 \\
\hline \multicolumn{15}{|l|}{ Metolachlor (post-emergence) } \\
\hline Emission to air (fraction) & $2.5 \mathrm{E}-03$ & $2.4 \mathrm{E}-03$ & $2.5 \mathrm{E}-03$ & $2.5 \mathrm{E}-03$ & $2.5 \mathrm{E}-03$ & $2.8 \mathrm{E}-03$ & $2.5 \mathrm{E}-03$ & $2.6 \mathrm{E}-03$ & $2.6 \mathrm{E}-03$ & $2.4 \mathrm{E}-03$ & $2.8 \mathrm{E}-03$ & $2.5 \mathrm{E}-03$ & $1.1 \mathrm{E}-04$ & 4.5 \\
\hline $\begin{array}{l}\text { Emission to surface water or off-field } \\
\text { soil (fraction) }\end{array}$ & $2.0 \mathrm{E}-02$ & 2.0E-02 & $2.0 \mathrm{E}-02$ & $2.0 \mathrm{E}-02$ & $2.0 \mathrm{E}-02$ & $2.0 \mathrm{E}-02$ & $2.0 \mathrm{E}-02$ & $2.0 \mathrm{E}-02$ & $2.0 \mathrm{E}-02$ & $2.0 \mathrm{E}-02$ & $2.0 \mathrm{E}-02$ & $2.0 \mathrm{E}-02$ & $3.8 \mathrm{E}-05$ & 0.2 \\
\hline Emission to groundwater (fraction) & $2.0 \mathrm{E}-03$ & $1.7 \mathrm{E}-03$ & $1.9 \mathrm{E}-03$ & $5.1 \mathrm{E}-03$ & $3.8 \mathrm{E}-03$ & $3.4 \mathrm{E}-03$ & $1.9 \mathrm{E}-03$ & $4.5 \mathrm{E}-03$ & $2.5 \mathrm{E}-03$ & $1.7 \mathrm{E}-03$ & $5.1 \mathrm{E}-03$ & $3.0 \mathrm{E}-03$ & $1.3 \mathrm{E}-03$ & 42.3 \\
\hline Degradation and uptake (fraction) & 9.8E-01 & $9.8 \mathrm{E}-01$ & 9.7E-01 & $9.7 \mathrm{E}-01$ & $9.7 \mathrm{E}-01$ & $9.7 \mathrm{E}-01$ & $9.8 \mathrm{E}-01$ & 9.7E-01 & $9.8 \mathrm{E}-01$ & $9.7 \mathrm{E}-01$ & $9.8 \mathrm{E}-01$ & $9.7 \mathrm{E}-01$ & $1.3 \mathrm{E}-03$ & 0.1 \\
\hline Cypermethrin (insecticides) & & & & & & & & & & & & & & \\
\hline
\end{tabular}


Emission to air (fraction)

Emission to surface water or off-field

soil (fraction)

\begin{tabular}{|c|c|c|c|c|c|c|c|c|c|c|c|c|c|}
\hline $4.1 \mathrm{E}-04$ & $4.1 \mathrm{E}-04$ & $4.1 \mathrm{E}-04$ & $4.1 \mathrm{E}-04$ & $4.1 \mathrm{E}-04$ & $4.1 \mathrm{E}-04$ & $4.1 \mathrm{E}-04$ & $4.1 \mathrm{E}-04$ & $4.1 \mathrm{E}-04$ & $4.1 \mathrm{E}-04$ & $4.1 \mathrm{E}-04$ & $4.1 \mathrm{E}-04$ & $4.1 \mathrm{E}-08$ & 0.0 \\
\hline $2.7 \mathrm{E}-04$ & $2.7 \mathrm{E}-04$ & $2.7 \mathrm{E}-04$ & $2.7 \mathrm{E}-04$ & $2.7 \mathrm{E}-04$ & $2.7 \mathrm{E}-04$ & $2.7 \mathrm{E}-04$ & $2.7 \mathrm{E}-04$ & $2.7 \mathrm{E}-04$ & $2.7 \mathrm{E}-04$ & $2.7 \mathrm{E}-04$ & $2.7 \mathrm{E}-04$ & $1.3 \mathrm{E}-09$ & 0.0 \\
\hline $5.2 \mathrm{E}-02$ & $5.5 \mathrm{E}-02$ & $4.6 \mathrm{E}-02$ & $7.5 \mathrm{E}-02$ & $6.9 \mathrm{E}-02$ & $5.6 \mathrm{E}-02$ & $4.8 \mathrm{E}-02$ & $6.9 \mathrm{E}-02$ & $4.8 \mathrm{E}-02$ & $4.6 \mathrm{E}-02$ & $7.5 \mathrm{E}-02$ & $5.9 \mathrm{E}-02$ & $1.0 \mathrm{E}-02$ & 18.5 \\
\hline $9.5 \mathrm{E}-01$ & $9.4 \mathrm{E}-01$ & $9.5 \mathrm{E}-01$ & $9.2 \mathrm{E}-01$ & $9.3 \mathrm{E}-01$ & $9.4 \mathrm{E}-01$ & $9.5 \mathrm{E}-01$ & $9.3 \mathrm{E}-01$ & $9.5 \mathrm{E}-01$ & $9.2 \mathrm{E}-01$ & $9.5 \mathrm{E}-01$ & $9.4 \mathrm{E}-01$ & $1.1 \mathrm{E}-02$ & 1.1 \\
\hline
\end{tabular}

Emission to groundwater (fraction)

Degradation and uptake (fraction)

Table 5. Distributions of pesticide among the environmental compartments obtained with Pest LCI 2.0 model using site-specific data (TDF1) and

those obtained applying data of soils with different characteristics. Figures indicate the fraction of pesticide emitted in each environmental compartment.

\begin{tabular}{|c|c|c|c|c|c|c|c|c|c|c|c|c|}
\hline Terbuthylazine (pre-emergence) & TDF1 & VAN1 & VED1 & MEL1 & CAP1 & SAB1 & VAD1 & MIN & MAX & Average & Stand.Dev. & c.v. $\%$ \\
\hline Emission to air (fraction) & 9.3E-02 & 9.3E-02 & 9.3E-02 & 9.3E-02 & 9.3E-02 & 9.3E-02 & $9.3 \mathrm{E}-02$ & $9.3 \mathrm{E}-02$ & 9.3E-02 & 9.3E-02 & $5.6 \mathrm{E}-05$ & 0.1 \\
\hline Emission to surface water or off-field soil (fraction) & $1.1 \mathrm{E}-03$ & $1.1 \mathrm{E}-03$ & $1.1 \mathrm{E}-03$ & $1.1 \mathrm{E}-03$ & $1.1 \mathrm{E}-03$ & $1.0 \mathrm{E}-03$ & $1.0 \mathrm{E}-03$ & $1.0 \mathrm{E}-03$ & $1.1 \mathrm{E}-03$ & $1.1 \mathrm{E}-03$ & 2.9E-05 & 2.7 \\
\hline Emission to groundwater (fraction)+ & $3.0 \mathrm{E}-01$ & $1.4 \mathrm{E}-01$ & $2.1 \mathrm{E}-01$ & $2.8 \mathrm{E}-02$ & $2.8 \mathrm{E}-02$ & $2.8 \mathrm{E}-02$ & $2.8 \mathrm{E}-02$ & $2.8 \mathrm{E}-02$ & $3.0 \mathrm{E}-01$ & $1.2 \mathrm{E}-01$ & $1.1 \mathrm{E}-01$ & 102 \\
\hline Degradation and uptake (fraction) & $6.1 \mathrm{E}-01$ & 7.7E-01 & 7.0E-01 & $8.8 \mathrm{E}-01$ & $8.8 \mathrm{E}-01$ & $8.8 \mathrm{E}-01$ & $8.8 \mathrm{E}-01$ & $6.1 \mathrm{E}-01$ & $8.8 \mathrm{E}-01$ & $7.8 \mathrm{E}-01$ & $1.1 \mathrm{E}-01$ & 14 \\
\hline \multicolumn{13}{|l|}{ Terbuthylazine (post-emergence) } \\
\hline Emission to air (fraction) & $1.2 \mathrm{E}-01$ & $1.2 \mathrm{E}-01$ & $1.2 \mathrm{E}-01$ & $1.2 \mathrm{E}-01$ & $1.2 \mathrm{E}-01$ & $1.2 \mathrm{E}-01$ & $1.2 \mathrm{E}-01$ & $1.2 \mathrm{E}-01$ & $1.2 \mathrm{E}-01$ & $1.2 \mathrm{E}-01$ & $1.3 \mathrm{E}-06$ & 0.0 \\
\hline Emission to surface water or off-field s & $1.3 \mathrm{E}-03$ & $1.3 \mathrm{E}-03$ & $1.3 \mathrm{E}-03$ & $1.3 \mathrm{E}-03$ & $1.3 \mathrm{E}-03$ & $1.2 \mathrm{E}-03$ & $1.2 \mathrm{E}-03$ & $1.2 \mathrm{E}-03$ & $1.3 \mathrm{E}-03$ & $1.2 \mathrm{E}-03$ & $2.2 \mathrm{E}-05$ & 1.8 \\
\hline Emission to groundwater (fraction) & $1.7 \mathrm{E}-01$ & $9.7 \mathrm{E}-02$ & $1.4 \mathrm{E}-01$ & $2.2 \mathrm{E}-02$ & $2.2 \mathrm{E}-02$ & $2.2 \mathrm{E}-02$ & $2.2 \mathrm{E}-02$ & $2.2 \mathrm{E}-02$ & $1.7 \mathrm{E}-01$ & $8.2 \mathrm{E}-02$ & $6.7 \mathrm{E}-02$ & 91.6 \\
\hline Degradation and uptake (fraction) & $7.1 \mathrm{E}-01$ & $7.8 \mathrm{E}-01$ & 7.3E-01 & $8.6 \mathrm{E}-01$ & $8.6 \mathrm{E}-01$ & $8.6 \mathrm{E}-01$ & $8.6 \mathrm{E}-01$ & $7.1 \mathrm{E}-01$ & $8.6 \mathrm{E}-01$ & $8.0 \mathrm{E}-01$ & $6.8 \mathrm{E}-02$ & 8.5 \\
\hline \multicolumn{13}{|l|}{ Metolachlor (pre-emergence) } \\
\hline Emission to air (fraction) & 7.7E-05 & $1.6 \mathrm{E}-04$ & $7.8 \mathrm{E}-05$ & $5.0 \mathrm{E}-04$ & $2.7 \mathrm{E}-04$ & $1.3 \mathrm{E}-04$ & $1.4 \mathrm{E}-03$ & 7.7E-05 & $1.4 \mathrm{E}-03$ & $3.5 \mathrm{E}-04$ & 4.9E-04 & 141 \\
\hline Emission to surface water or off-fiel & $9.5 \mathrm{E}-03$ & $9.6 \mathrm{E}-03$ & 9.5E-03 & 9.7E-03 & $9.6 \mathrm{E}-03$ & $9.4 \mathrm{E}-03$ & $1.9 \mathrm{E}-02$ & $9.4 \mathrm{E}-03$ & $1.9 \mathrm{E}-02$ & $1.1 \mathrm{E}-02$ & $3.4 \mathrm{E}-03$ & 32.3 \\
\hline Emission to groundwater (fraction) & $2.6 \mathrm{E}-03$ & $2.5 \mathrm{E}-03$ & $2.1 \mathrm{E}-03$ & 4.3E-03 & $3.2 \mathrm{E}-03$ & $2.2 \mathrm{E}-03$ & $7.5 \mathrm{E}-03$ & $2.1 \mathrm{E}-03$ & $7.5 \mathrm{E}-03$ & $3.4 \mathrm{E}-03$ & $1.9 \mathrm{E}-03$ & 55 \\
\hline Degradation and uptake (fraction) & 9.9E-01 & 9.9E-01 & 9.9E-01 & 9.9E-01 & 9.9E-01 & 9.9E-01 & $9.7 \mathrm{E}-01$ & 9.7E-01 & 9.9E-01 & 9.9E-01 & $5.8 \mathrm{E}-03$ & 0.6 \\
\hline \multicolumn{13}{|l|}{ Metolachlor (post-emergence) } \\
\hline Emission to air(fraction) & $2.5 \mathrm{E}-03$ & 2.6E-03 & $2.5 \mathrm{E}-03$ & $3.0 \mathrm{E}-03$ & $2.7 \mathrm{E}-03$ & $2.5 \mathrm{E}-03$ & 4.2E-03 & $2.5 \mathrm{E}-03$ & 4.2E-03 & $2.8 \mathrm{E}-03$ & $6.1 \mathrm{E}-04$ & 21.6 \\
\hline Emission to surface water or off-field soil(fraction) & $2.0 \mathrm{E}-02$ & $2.0 \mathrm{E}-02$ & $2.0 \mathrm{E}-02$ & 2.0E-02 & $2.0 \mathrm{E}-02$ & $2.0 \mathrm{E}-02$ & $2.0 \mathrm{E}-02$ & $2.0 \mathrm{E}-02$ & $2.0 \mathrm{E}-02$ & $2.0 \mathrm{E}-02$ & $6.4 \mathrm{E}-05$ & 0.3 \\
\hline Emission to groundwater (fraction) & $2.0 \mathrm{E}-03$ & $2.0 \mathrm{E}-03$ & $1.6 \mathrm{E}-03$ & $3.4 \mathrm{E}-03$ & $2.5 \mathrm{E}-03$ & $1.8 \mathrm{E}-03$ & $5.9 \mathrm{E}-03$ & $1.6 \mathrm{E}-03$ & $5.9 \mathrm{E}-03$ & $2.6 \mathrm{E}-03$ & $1.4 \mathrm{E}-03$ & 55.8 \\
\hline Degradation and uptake (fraction) & 9.8E-01 & 9.8E-01 & 9.8E-01 & 9.7E-01 & $9.8 \mathrm{E}-01$ & $9.8 \mathrm{E}-01$ & $9.7 \mathrm{E}-01$ & 9.7E-01 & $9.8 \mathrm{E}-01$ & 9.7E-01 & $2.0 \mathrm{E}-03$ & 0.2 \\
\hline
\end{tabular}




\begin{tabular}{|c|c|c|c|c|c|c|c|c|c|c|c|c|}
\hline Cypermethrin (insecticides) & & & & & & & & & & & & \\
\hline Emission to air (fraction) & $4.1 \mathrm{E}-04$ & $4.1 \mathrm{E}-04$ & $4.1 \mathrm{E}-04$ & 4.1E-04 & 4.1E-04 & 4.1E-04 & 4.1E-04 & $4.1 \mathrm{E}-04$ & $4.1 \mathrm{E}-04$ & 4.1E-04 & 4.3E-08 & 0.0 \\
\hline Emission to surface water or off-field soil (fraction) & $2.7 \mathrm{E}-04$ & $2.7 \mathrm{E}-04$ & $2.7 \mathrm{E}-04$ & $2.7 \mathrm{E}-04$ & $2.7 \mathrm{E}-04$ & 2.7E-04 & $2.7 \mathrm{E}-04$ & $2.7 \mathrm{E}-04$ & $2.7 \mathrm{E}-04$ & $2.7 \mathrm{E}-04$ & $2.4 \mathrm{E}-09$ & 0.0 \\
\hline Emission to groundwater (fraction) & $5.2 \mathrm{E}-02$ & $2.5 \mathrm{E}-02$ & $4.2 \mathrm{E}-02$ & $2.3 \mathrm{E}-06$ & $1.6 \mathrm{E}-06$ & $1.1 \mathrm{E}-06$ & 4.6E-06 & $1.1 \mathrm{E}-06$ & $5.2 \mathrm{E}-02$ & $2.1 \mathrm{E}-02$ & $2.3 \mathrm{E}-02$ & 133 \\
\hline
\end{tabular}

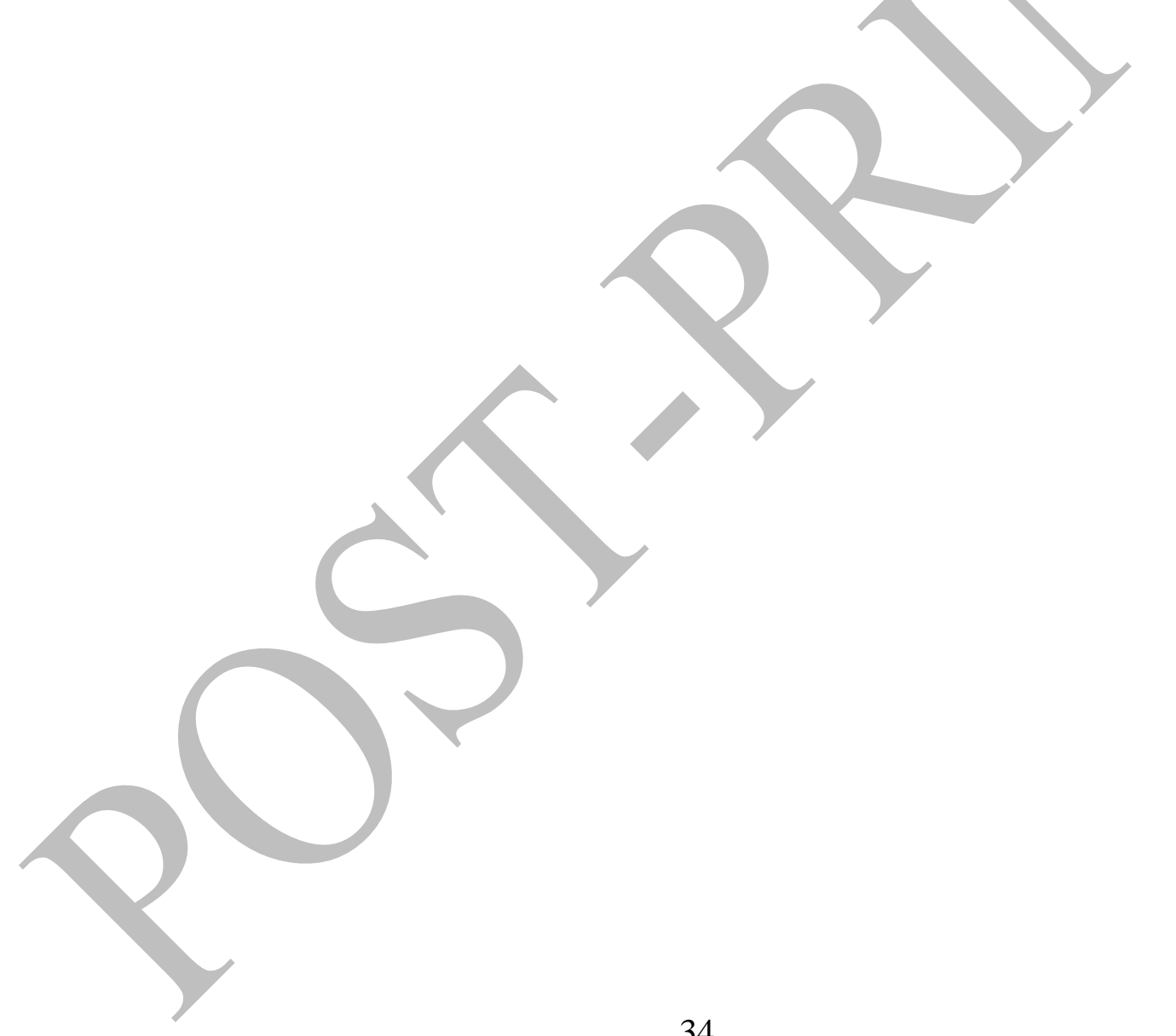


Table 6. Results of the application of PestLCI 2.0 model for each active ingredient and for TDF1 soil and Soil6. Values indicate the fraction of pesticide emitted in each environmental compartment.

\begin{tabular}{|l|c|c|c|}
\hline Terbuthylazine (pre-emergence) & TDF1 & Soil6 & \% Difference \\
\hline Emission to air (fraction) & $9.3 \mathrm{E}-02$ & $9.3 \mathrm{E}-02$ & $0 \%$ \\
\hline Emission to surface water or off-field soil (fraction) & $1.1 \mathrm{E}-03$ & $1.1 \mathrm{E}-03$ & $0 \%$ \\
\hline Emission to ground water (fraction) & $3.0 \mathrm{E}-01$ & $4.1 \mathrm{E}-01$ & $35 \%$ \\
\hline Degradation and uptake (fraction) & $6.1 \mathrm{E}-01$ & $5.0 \mathrm{E}-01$ & $-17 \%$ \\
\hline Terbuthylazine (post-emergence) & & & \\
\hline Emission to air (fraction) & $1.2 \mathrm{E}-01$ & $1.2 \mathrm{E}-01$ & $0 \%$ \\
\hline Emission to surface water or off-field soil (fraction) & $1.3 \mathrm{E}-03$ & $1.3 \mathrm{E}-03$ & $0 \%$ \\
\hline Emission to ground water (fraction) & $1.7 \mathrm{E}-01$ & $2.8 \mathrm{E}-01$ & $63 \%$ \\
\hline Degradation and uptake (fraction) & $7.1 \mathrm{E}-01$ & $6.0 \mathrm{E}-01$ & $-15 \%$ \\
\hline Metolachlor (pre-emergence) & & & \\
\hline Emission to air (fraction) & $7.7 \mathrm{E}-05$ & $4.7 \mathrm{E}-05$ & $-39 \%$ \\
\hline Emission to surface water or off-field soil (fraction) & $9.5 \mathrm{E}-03$ & $9.5 \mathrm{E}-03$ & $0 \%$ \\
\hline Emission to ground water (fraction) & $2.6 \mathrm{E}-03$ & $1.6 \mathrm{E}-02$ & $500 \%$ \\
\hline Degradation and uptake (fraction) & $9.9 \mathrm{E}-01$ & $9.7 \mathrm{E}-01$ & $-1 \%$ \\
\hline Metolachlor (post-emergence) & & & \\
\hline Emission to air (fraction) & $2.5 \mathrm{E}-03$ & $2.4 \mathrm{E}-03$ & $-2 \%$ \\
\hline Emission to surface water or off-field soil (fraction) & $2.0 \mathrm{E}-02$ & $2.0 \mathrm{E}-02$ & $0 \%$ \\
\hline Emission to ground water (fraction) & $2.0 \mathrm{E}-03$ & $1.1 \mathrm{E}-02$ & $455 \%$ \\
\hline Degradation and uptake (fraction) & $9.8 \mathrm{E}-01$ & $9.7 \mathrm{E}-01$ & $-1 \%$ \\
\hline Cypermethrin (insecticides) & & & \\
\hline Emission to air (fraction) & $4.1 \mathrm{E}-04$ & $4.8 \mathrm{E}-04$ & $17 \%$ \\
\hline Emission to surface water or off-field soil (fraction) & $2.7 \mathrm{E}-04$ & $2.7 \mathrm{E}-04$ & $0 \%$ \\
\hline Emission to ground water (fraction) & $5.2 \mathrm{E}-02$ & $9.7 \mathrm{E}-02$ & $85 \%$ \\
\hline Degradation and uptake (fraction) & $9.5 \mathrm{E}-01$ & $9.0 \mathrm{E}-01$ & $-5 \%$ \\
\hline
\end{tabular}

